\title{
STRATEGI PEMBANGUNAN DAN PELABURAN WAKAF SECARA LESTARI MENURUT PERSPEKTIF SYARIAH
}

\author{
The Strategy of Sustainable Waqf Development \\ and Investment from the Perpective of Shariah
}

\author{
Syahnaz Sulaiman ${ }^{1}$ \\ Aznan Hasan ${ }^{2}$
}

\begin{abstract}
The initiative towards enhancing the role of waqf as the main driving force for socioeconomic development of the ummah has received tremendous support from the Muslim community globally. Much effort has been concerted by various waqf stakeholders to strengthen the role of the waqf institution as a socio-economic driving force which strives for the betterment of the global Muslim community. Special focus has been given to waqf development and investment agendas towards preserving waqf assets particularly in generating stable income in order to meet its objectives. Therefore, this study will explore the concept of sustainable waqf development and investment from the Islamic perspective and how strategic waqf development and investment approach may be implemented in light of the Shariah. The data used in this study was obtained from the literature review which
\end{abstract}

\footnotetext{
1 Senior Assistant Director, Strategic Planning and Research Division, Department of Islamic Development Malaysia, syahnaz@islam.gov.my

2 Associate Professor, IIUM Institute of Islamic Banking and Finance Institution (IIiBF), International Islamic University Malaysia, aznanh@gmail.com
} 
was then analysed by using content and textual analysis technique. The findings further underline the strategy of sustainable waqf asset development and investment which should serve as a guide for the waqf administrators in the realization of sustainable development and investment in order to enhance the income of waqf assets for the benefit and welfare of the ummah.

Keywords: waqf, strategy of sustainable waqf development and investment

\section{PENDAHULUAN}

Sejak dahulu lagi, institusi wakaf telah berperanan dalam menyediakan kemudahan bagi memenuhi tuntutan dan keperluan sosial umat Islam menerusi pembinaan pelbagai infrastruktur untuk kegunaan masyarakat seperti hospital dan penyediaan bekalan air serta bagi tujuan keagamaan meliputi pembinaan masjid, madrasah, sekolah agama dan tanah perkuburan. Sejarah telah membuktikan bahawa wakaf telah memainkan peranan yang besar dalam pembinaan peradaban serta kekayaan milik umat Islam di seluruh dunia semenjak zaman Nabi Muhammad SAW sehingga ke hari ini. Wakaf turut berperanan bagi mencapai objektif filantropi dengan matlamat untuk membasmi kemiskinan dan menyediakan kemudahan awam kepada masyarakat dalam sektor pendidikan, penjagaan kesihatan, pertanian, kajian saintifik dan pembiayaan perniagaan. ${ }^{3}$ Aset wakaf bukan sahaja terdiri daripada aset berkualiti tinggi yang menjana pendapatan seperti kompleks komersial dan hotel bahkan turut menyediakan peluang pekerjaan kepada anggota masyarakat. ${ }^{4}$ Idea dan konsep wakaf itu sendiri merupakan suatu prinsip yang menjadi aspirasi dalam menentukan hala tuju pembangunan institusi tidak bermotifkan keuntungan (non-profitorganisation/NPO) dan tidak berkaitan kerajaan (non-governmental organisation $\mathrm{NGO}$ ) bagi meningkatkan kuantiti dan kualiti perkhidmatan kebajikan ummah. ${ }^{5}$

Tidak dinafikan bahawa wakaf merupakan suatu konsep yang mempunyai kekuatan dengan struktur yang dinamik dan mekanisme yang fleksibel ke arah melahirkan produk dan perkhidmatan bagi memenuhi keperluan dan

3 Shukti Adam dan Ahcene Lahsana, 'Cash Endowment As Source of Fund in Islamic Micro-Financing,' (Kertas kerja yang dibentangkan dalam 4th International Conference on Business and Economic Research (4th ICBER 2013), Bandung Indonesia, 4 Mac 2013), 1363.

4 Magda Ismail Abdel Mohsin, 'Revitalization of Waqf Administration and Family Waqf Law,' China Law Review, 7/6 (June 2010): 1.

5 Monzer Kahf, 'Financing the Development of Awqaf Property,' (Kertas kerja yang dibentangkan dalam Seminar on Development of Awqaf, Kuala Lumpur, 2-4 Mac 1998), 1. 
kepentingan masyarakat. Wakaf secara tidak langsung menganjurkan nilai pembangunan dan pelaburan yang bersifat holistik dan lestari yang hasilnya dapat dinikmati dan dituai secara berterusan bukan sahaja di dunia bahkan hingga ke akhirat.

\section{DEFINISI DAN DALIL PENSYARIATAN WAKAF}

Dalam konteks muamalat Islam, al-waqf adalah sinonim dengan al-habs yang bermaksud penahanan, al-man ' bererti larangan ${ }^{6}$ serta al-tasbīl iaitu menyalurkan pada jalan Allah SWT. ${ }^{7}$ Jumhur fuqaha mendefinisikan wakaf sebagai suatu dedikasi harta dengan menahan harta tersebut daripada sebarang pemindahan pemilikan dan manfaatnya disalurkan bagi tujuan kebajikan khusus untuk mendekatkan diri kepada Allah SWT. ${ }^{8}$ Pensyariatan wakaf adalah selaras dengan firman Allah SWT:

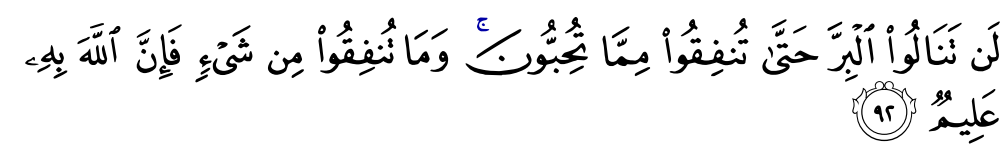

"Kamu tidak sekali-kali akan dapat mencapai kebajikan (yang sempurna) sebelum kamu dermakan sebahagian daripada apa yang kamu sayangi. Dan sesuatu apa jua yang kamu dermakan maka sesungguhnya Allah mengetahuinya"

(Surah Āli-'Imrān, 3: 92)

Mustafa al-Khin, Mustafa al-Bugha dan 'Ali al-Syarbaji menjelaskan bahawa frasa "kebajikan" membawa maksud segala bentuk kebaikan

$6 \quad$ Shams al-Dīn al-Sarakhsī, al-Mabșūt, vol. 12 (Beirūt: Dār al-Ma'rifah, t.t), 27.

7 Abi Muhammad 'Abd Allāh bin Aḥmad bin Muḥammad bin Qudāmah, al-Mughn̄, vol. 8 (Arab Saudi: Dār 'Alam al-Kutub, 1997), 184; Manșūr bin Yūsuf al-Buhūṭī, Kasshāf al-Qinā' 'an al-Iqnā', vol. 10 (Arab Saudi: Wizārah al-'Adl), 5; Muḥy al-Dīn al-Nawāwī, al-Majmū' Sharh al-Muhaddhab li al-Shīrāzī, vol. 16 (Jeddah: Maktabah al-Irsyād, t.t.), 243.

8 Burhān al-Dīn Ibrāhim bin Mūṣā bin Abī Bakr ibn al-Syakh 'Alī al-Ṭarābulsī, al-Is 'äf fi al-Ahkām al-Awqāf (Mesir: Matba 'ah Hindiyyah, 1902), 3; 'Alaw al-

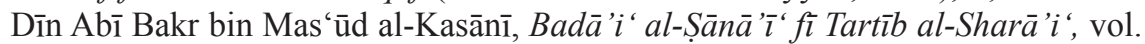
8 (Dār al-Kitāb al-'Ilmiyyah), 385; Shams al-Dīn Muhammad bin al-Khatīb alSharbin̄̄, Mughn̄̄ al-Muhtāj ilā Ma 'rifati Alfāz al-Minhāj, vol. 2 (Beirūt: Dār al-Ma'rifah, 1997), 485. 
yang merujuk kepada wakaf. ${ }^{9}$ Manakala dalil hadis yang terkenal adalah sebagaimana yang diriwayatkan oleh Ibn 'Umar perihal ayahandanya Saidina 'Umar al-Khattāb yang telah mewakafkan tanahnya yang terbaik di daerah Khaybar. Hasil daripada tanah yang "diwakafkan” itu telah diagihkan kepada fakir miskin, kaum keluarga, hamba abdi, orang yang berada di jalan Allah (fi sabïlillah), ibn sabīl dan para tetamu. ${ }^{10}$ Hadis tersebut turut menggariskan prinsip-prinsip utama yang mendasari konsep wakaf yakni tidak boleh dijual, dihibah dan diwarisi. Perwakafan oleh Saidina 'Umar berupa sebuah ladang bernama thamgh di Khaybar yang turut menjana hasil pertanian merupakan suatu manifestasi berhubung pensyariatan wakaf di samping telah disepakati oleh jumhur fuqaha sebagai antara wakaf yang pertama dalam sejarah Islam. ${ }^{11}$

Hadis tersebut mengandungi fundamental yang jelas bahawa harta yang diwakafkan bukanlah terdiri daripada harta yang terpendam, kosong dan terbiar sebaliknya terdiri daripada harta yang dimajukan dan mempunyai hasil untuk disalurkan kepada kepentingan orang ramai. Realiti ini agak berbeza dengan wakaf yang dilaksanakan oleh segelintir masyarakat Melayu apabila mereka mewakafkan hartanah yang tidak mempunyai potensi komersial, ${ }^{12}$ berada di kawasan yang jauh terpencil dengan saiz yang kecil serta tidak ekonomik sehingga sukar untuk dibangunkan. Senario ini seterusnya memberi cabaran kepada pentadbir wakaf di Malaysia selaku pemegang amanah tunggal untuk

9 Al-Khin, Mustafa, al-Bugho, Mustafa dan 'Ali al-Syarbaji, al-Fiqh al-Manhaji 'ala Mazhabi al-Imam al-Shāfi 'i, Kitab Wakaf, Wasiat dan Faraid (terj), vol. 5 (Kuala Lumpur: Pustaka Salam Sdn Bhd., 2009), 934.

10 Hadis ini telah diriwayatkan oleh semua perawi dalam Sunan al-Sittah. Lihat AlShaykh Șālih Ibn 'Abd al-'Azīz Ibn Muḥammad, Mawsū 'ah al-Hāàith al-Sharif: al-Kutub al-Sittah: Șaḥị̣ al-Bukhārī, Șahịh Muslim, Sunan Abī Dāwūd, Jami‘ al-Tirmidhī, Sunan al-Nasa'̄̄, Sunan Ibn Mājah (Riyāḍ: Dār al-Salām, 2008). al-Bukhārī, kitāb al-wașāya, bāb ma li al-wașiyyi al-ya 'mal fì māl al-yatīm, no. hadis 2764, 223; Șah̄ị Muslim, kitāb al-Wașiyyah, bab al-waqf, hadis no. 4224, 963; Sunan Abī Dāwud, kitāb al-Farā'id, bab mā jā'a fì al-rajul yuqāfu al-waqf, hadis no. 2878, 1438; Jami' al-Tirmidhī, bab ma jā'a fì al-waqf, no. hadis. 1375, 1791; Al-Nasai'y, kitab al-Ihbas, hadis no. 3637, 2326; Ibn Mājah, kitab Șadaqāt, abwāb al-Ṣadaqāt, hadis no. 2397, 2620.

11 Muștafā Aḥmad al-Zarqā, al-Aḥkām al-Awqāff ('Ammān: Dār 'Ammar, 1998), 11.

12 Menurut Tunku Alina, terdapat kecenderungan dalam masyarakat Melayu yang mana tanah yang mempunyai nilai komersil akan dibangunkan oleh pemilik tanah manakala tanah yang kurang mempunyai potensi komersial akan diwakafkan. Lihat Tunku Alina Raja Alias, 'Unleashing the Potential of the Waqf As an Economic Institution in Malaysia: Policy, Legal and Economic Reforms,' (Tesis, Ijazah Doktor Falsafah, International Centre for Education in Islamic Finance, Kuala Lumpur, 2011). 
membangunkan aset-aset wakaf ini sehingga mengakibatkan banyak hartanah wakaf masih belum digembleng secara sewajarnya berpunca daripada masalah kekurangan dana. Meskipun harta-harta yang kurang produktif ini masih sah sebagai subjek wakaf menurut hukum syarak, melihatkan kepada potensi harta wakaf, masyarakat seharusnya diberikan kesedaran bagi meningkatkan kefahaman mereka bahawa aset wakaf hendaklah terdiri daripada harta-harta yang produktif. Sekiranya sesuatu harta yang diwakafkan merupakan harta yang kurang berkualiti, maka pewakaf seharusnya memberi kebenaran kepada mutawalli (pemegang amanah) agar harta tersebut ditukarkan (istibdāl) dalam bentuk yang lain bagi membolehkannya dimanfaatkan.

Meskipun pada suatu ketika dahulu peranan wakaf telah mengalami kemerosotan $^{13}$ kerana tidak diurus secara efisien sebagai sebuah institusi kebajikan yang mempunyai fungsi dan kekuatan ekonomi, namun kini kesedaran bagi memberi nafas baharu terhadap fungsi wakaf semakin mendapat perhatian umat Islam. Kajian oleh Ali mendapati bahawa meskipun terdapat banyak harta wakaf di negara-negara Islam di seluruh dunia, aset-aset tersebut tidak dimajukan dan digembleng secara sewajarnya bagi menyediakan perkhidmatan kebajikan kepada umat Islam. ${ }^{14}$

Mohd. Zain menerusi kajiannya mendapati bahawa terdapat ramai sarjana Barat sekitar kurun ke 19 dan 20 yang berpendapat sejumlah besar daripada tanah-tanah wakaf telah diabaikan dan hasilnya juga kurang berbanding dengan kategori tanah yang lain. ${ }^{15}$ Sementara itu, Kuran menyifatkan konsep wakaf merupakan faktor yang menyebabkan berlakunya insiden kemiskinan dan kemunduran ekonomi di negara dan wilayah Islam disebabkan sebahagian besar sumber kekayaan telah dikeluarkan daripada industri. ${ }^{16}$ Konsep wakaf

13 Murat Cizakca, A History of Philanthropic Foundations: The Islamic World From the Seventh Century to the Present, Istanbul: Bogazici University Press, 2000), 3-4; Timur Kuran, 'Why the Middle East is Economically Underdeveloped : Historical Mechanisms of Institutional Stagnation', The Journal of Islamic Economic Perspectives, 18/3 (2012): 71-90; Timur Kuran, 'The Economic Roots of Political Underdevelopment in the Middle East: A Historical Perspective,' 78/4 (2012): 1093; Hidayatul Ihsan \& Shahul Hameed Mohamed Ibrahim, 'Waqf Accounting and Possible Use of SORP 2005 to Develop Waqf Accounting Standards,' dalam Essential Readings in Contemporary Waqf Issues, ed. Monzer Kahf \& Siti Mashitoh Mahamood (Kuala Lumpur: CERT Publications, 2011), 252.

14 Ashfaque Ali, 'Socio-Economic Role of Awqaf in the Advancement of Muslims,' Awqaf, 3 (2002): 21-30.

15 Mohd Zain Haji Othman, Islamic Law with Special Reference to the Institution of Waqf (Kuala Lumpur: Jabatan Perdana Menteri, 1982), 116.

16 Timur Kuran, 'Why the Middle East is Economically Underdeveloped: Historical Mechanisms of Institutional Stagnation,' 71-72. 
yang menekankan ciri-ciri kekal, tidak boleh dijual beli dan dipindah milik juga didakwa menjadi penghalang kepada institusi wakaf untuk berkembang sebagai sebuah organisasi bersifat komersil kerana sumber-sumbernya tidak diurus secara fleksibel. ${ }^{17}$ Institusi wakaf yang berorientasikan kebajikan juga dikatakan telah menghalang usaha pengumpulan dan pengembangan harta berdasarkan sistem pelaburan dan ekonomi moden yang lebih produktif di samping tidak mempunyai ciri-ciri institusi korporat yang berpengaruh dalam kerajaan. $^{18}$

Shatzmiller dan Kuran turut berpandangan bahawa faktor penyelewengan dan salah guna kuasa dalam pengurusan wakaf, ketiadaan kepakaran pengurusan organisasi berskala besar, iklim politik yang tidak menentu serta status wakaf yang tidak diiktiraf sebagai sebuah entiti syarikat dalam perbicaraan di mahkamah merupakan antara halangan-halangan yang menyekat usaha pembangunan wakaf secara dinamik. ${ }^{19}$ Cizakca serta Siraj dan Lim antara lain berpendapat bahawa dasar imperialisme dan kolonialisme oleh Barat adalah dalang yang menyebabkan kemunduran institusi wakaf di seluruh dunia Islam sekitar kurun ke-19 dan ke-20 ${ }^{20}$ namun fenomena ini tidak memberi kesan

17 Timur Kuran, 'The Absence of the Corporation in Islamic Law: Origins and Persistence,' American Journal of Comparative Law, 53/4 (2005): 785-834; Timur Kuran, 'Why the Middle East is Economically Underdeveloped: Historical Mechanisms of Institutional Stagnation,' 71-90; Lane, Jan-Erik, Redissi, Hamadi \& Șaydawi, Riyaḍ, Religion and Politics: Islam and Muslim Civilization (England: Ashgate Publishing Limited, 2009), 100.

18 Timur Kuran, 'The Economic Roots of Political Underdevelopment in the Middle East: A Historical Perspective,' Southern Economic Journal, 78/4 (2012): 10861095.

19 Shatzmiller Maya, 'Islamic Institutions and Property Rights: The Case of the 'Public Good' Waqf,' Journal of Economic and Social History of the Orient, 44/1 (2001): 44-74; Shatzmiller Maya, 'Economic Performance and Economic Growth in the Early Islamic World,' Journal of the Economic and Social History of the Orient, 54/2 (2011): 132-184; Timur Kuran, 'The Economic Roots of Political Underdevelopment in the Middle East: A Historical Perspective,' 1091. Timur Kuran, Islam and Mammon: The Economic Predicaments of Islamism (Princeton and Oxford: Princeton University Press, 2004), 78.

20 Beberapa pengkaji turut melaporkan berlakunya penyelewengan dalam pengurusan harta wakaf khususnya semasa era kerajaan Turki Uthmaniyyah sehingga membawa kepada kemerosotan sistem wakaf dan seterusnya kejatuhan empayar itu sendiri seperti penggelepan wang hasil wakaf, harta-harta wakaf terbiar dan tidak diselenggara dengan baik. Lihat Siraj Sait \& Hilary Lim, Land Law and Islam: Property Human Rights in the Muslim World (London: Zed Books Ltd, 2006), 159. 
terhadap kerajaan Turki memandangkan empayar tersebut tidak pernah dijajah oleh Barat. ${ }^{21}$

Dalam konteks hari ini, terdapat konsensus dalam kalangan komuniti Islam kontemporari di peringkat global bahawa institusi wakaf berupaya mengulangi sejarah kegemilangan untuk berperanan secara kritikal sebagai pemangkin memajukan sosioekonomi ummah. Atas kesedaran yang semakin tinggi dan menebal dalam kalangan pentadbir wakaf di Malaysia, usaha pembangunan aset wakaf kian diberikan perhatian serta menjadi agenda utama kerajaan bagi memperkasakan institusi ini. ${ }^{22}$

\section{TEORI PEMBANGUNAN DAN PELABURAN DALAM ISLAM}

Perkataan pembangunan dalam bahasa Arab ialah tanmiyah yang bermaksud pertambahan atau pengembangan. ${ }^{23}$ Menurut Miswan et al., pembangunan melibatkan proses transformasi atau perubahan daripada suatu keadaan yang tidak berhasil atau kurang berhasil kepada suatu keadaan yang lebih berhasil secara lebih produktif bagi melahirkan sesuatu yang berfaedah. ${ }^{24}$ Dapat difahami bahawa pembangunan melibatkan perubahan kepada keadaan yang lebih sempurna secara konsisten dalam segenap aspek kehidupan manusia daripada segi budaya, sosial, ekonomi, teknologi dan alam sekitar. ${ }^{25}$ Inti pati kepada perubahan yang positif ini berpaksikan kepada dua elemen utama iaitu kesamarataan dan keadilan dalam agihan hasil daripada pembangunan sehingga dapat dinikmati dan dirasai oleh setiap anggota masyarakat secara saksama. ${ }^{26}$ Apa yang lebih utama, kerangka pembangunan dalam Islam bertujuan untuk mencapai Maqāșid al-Syarī'ah (objektif Syariah) terutama

21 Murat Cizakca, A History of Philantropic Foundations, 1.

22 Jamil Khir Baharom, 'Ucaptama Menteri di Jabatan Perdana Menteri,' (Majlis Perasmian Seminar Waqaf Antarabangsa 2014, Hotel Istana, Kuala Lumpur, 7-10 Disember 2014).

23 Ni'mat 'Abd al-Lațīf Masyhūr, Athār al-Waqffì Tanmiyyah al-Mujtamā', (Qāhirah: Markaz Șāliḥ ‘Abd Allāh Kāmil li al-Iqtișād al-Islāmī, Jāmi'ah al-Azhār, 1977), 44.

24 Miswan@Abdul Hakim et al., 'Pembangunan Harta Tanah dan Pelestarian Alam' (Kertas kerja yang dibentangkan dalam Seminar Pembangunan Harta Tanah Kebangsaan Menurut Perspektif Islam, Institut Kefahaman Islam Malaysia, Kuala Lumpur, 11-12 Ogos 2009), 2.

25 Hugo Slim, 'What is Development,' Development in Practice, 5/2 (May, 1995), 143.

26 Hugo Slim, 'What is Development,' 143-144. 
sekali dalam aspek pemeliharaan harta bagi menjamin kerukunan kehidupan manusia di muka bumi ini. ${ }^{27}$

Pembangunan juga dianggap sebagai suatu bentuk "khidmat kepada Allah SWT" (service to God). ${ }^{28}$ Manusia sebagai khalifah yang diamanahkan oleh Allah SWT telah ditaklïfkan untuk memakmurkan bumi dengan mengurus dan memajukan harta secara optimum bagi membolehkan mereka mendiami dunia ini dengan penuh kesenangan berdasarkan firman Allah SWT:

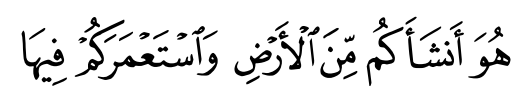

“...Dialah yang menjadikan kamu daripada bahan-bahan bumi, serta menghendaki kamu memakmurkannya..." 29

Jelas sekali bahawa sebarang bentuk pembekuan harta tanpa sebarang usaha adalah dilarang dalam Islam.

Pembangunan menurut kerangka Islam adalah berbeza dengan konsep pembangunan menurut kaca mata Barat yang dilihat lebih menekankan aspek keuntungan material serta tidak mempunyai jiwa. ${ }^{30}$ Berbeza sekali dengan dasar pembangunan dalam Islam yang mempunyai nilai-nilai luhur bagi mengimbangi antara tuntutan duniawi dan ukhrawi menerusi pembangunan bersifat dualisme daripada sudut rohani dan jasmani. Kurshid ${ }^{31}$ telah merumuskan konsep pembangunan dalam Islam merangkumi empat dimensi utama iaitu tauhid (keesaan Allah SWT), rububiyyah (Allah SWT sebagai Tuhan yang melimpahkan rahmat), khalifah dan tazkiyyah ${ }^{32}$ (penyucian).

27 Monzer Kahf, Asasiyyat al-Tamwil al-Islamiy (ISRA: Kuala Lumpur, 2011), 17 18.

28 Ziauddin Sardar, 'Beyond Development: An Islamic Perspective,' The European Journal of Development Research, 8/2 (Special Issue: Cultural Perspectives on Development, 1996), 47.

29 Surah Hud (11): 61.

30 Nik Mohd Zain Haji Yusof \& Azimuddin Bahari, 'Kedudukan dan Potensi Pembangunan Hartanah Wakaf di Malaysia: Satu Penilaian,' dalam Konsep dan Pelaksanaan Wakaf di Malaysia, ed. Nik Mustapha Nik Hassan (Kuala Lumpur: Institut Kefahaman Islam Malaysia (IKIM), 1999), 110.

31 Ahmad, Kurshid, 'Economic Development in An Islamic Framework,' in Studies in Islamic Economics, ed. Ahmad, Kurshid (Leicester: Islamic Foundation, 1980).

32 Kursyid telah merumuskan bahawa konsep tazkiyyah didasari oleh enam elemen iaitu zikir, ibadah, taubat, sabar, muhasabah dan doa. 
Manakala Siddiqi merangkumkannya menerusi elemen tazkiyyah (pembangunan kerohanian menerusi penyucian jiwa); tarbiyyah (pembangunan akhlak); tanmiyyah (pembangunan sosial dan ekonomi); tatawwur (pembangunan pendidikan dan budaya); dan taqaddum (pembangunan ketamadunan). ${ }^{33}$ Kesyumulan konsep pembangunan harta dalam Islam turut disebut oleh Mohd Daud sebagai mempunyai dasar yang murni bagi menghalang kerosakan alam, menggalakkan kecekapan dan kelangsungan alam serta pengagihan kekayaan dan harta secara adil dan saksama dalam masyarakat. ${ }^{34}$

Nik Mohd Zain dan Azimuddin seterusnya meletakkan tazkiyyah sebagai teras pembangunan dalam Islam yang melibatkan unsur pertumbuhan dan pengembangan menerusi penyucian sikap dan hubungan sesama insan. ${ }^{35}$ Sehubungan itu, Islam telah menginstitusikan beberapa instrumen ekonomi berasaskan Syariah seperti zakat dan wakaf ke arah merealisasikan konsep tazkiyyah iaitu pembangunan sosio dan ekonomi menerusi pembersihan harta dan jiwa dan hasilnya berupa al-falāh (kejayaan) yakni kemajuan dunia dan akhirat.

Konsep al-falāh yang begitu holistik menuntut keseimbangan keperluan material dan spiritual manusia meliputi kesejahteraan kerohanian, kebudayaan dan politik serta keadilan sosial dan ekonomi di samping memperoleh keredhaan Allah SWT di akhirat kelak. ${ }^{36}$

Manakala pelaburan ialah aktiviti ekonomi bagi meningkatkan kekayaan untuk mendapatkan keuntungan menerusi beberapa akad seperti mud̄ārabah, muṣhārakah dan muzāra 'ah yang diharuskan dalam Islam. ${ }^{37}$ Pelaburan dalam

33 Siddiqi, Muzammil H., Principles and Goals of Development: An Islamic Perspective. Dipetik daripada Miswan@Abdul Hakim Mohammed et al., 'Pembangunan Harta Tanah dan Pelestarian Alam,' (Kertas kerja yang dibentangkan dalam Seminar Pembangunan Harta Tanah Kebangsaan Menurut Perspektif Islam, Dewan Besar Insitut Kefahaman Islam Malaysia (IKIM), Kuala Lumpur, 11-12 Ogos 2009), 5.

34 Mohd Daud Bakar, 'Konsep dan Matlamat Harta dalam Pembangunan Ummah,' dalam Pentdbiran Harta Menurut Islam, ed. Abdul Monir Yaacob \& Mohd. Fauzi Mustaffa (Kuala Lumpur: IKIM, 1999), 1-24.

35 Nik Mohd Zain Haji Yusof \& Azimuddin Bahari, 'Kedudukan dan Potensi Pembangunan Hartanah Wakaf di Malaysia: Satu Penilaian,' 111.

36 Khan, Muhammad Akram, 'The Future of Islamic Economics,' Futures, 23/3 (1991): 248-261.

37 International Shariah Research Academy for Islamic Finance (ISRA), ISRA Compendium for Islamic Financial Terms: Arabic-English (International Shariah Research Academy for Islamic Finance (ISRA): Kuala Lumpur, 2010), 213. 
konteks ekonomi melibatkan penanaman modal oleh unit lebihan kepada unit kurangan dengan jangkaan mendapat keuntungan pada masa hadapan setelah mengambil kira segala bentuk risiko yang mungkin berlaku. ${ }^{38}$ Pada dasarnya pelaburan melibatkan aktiviti pengembangan serta penggemblengan harta secara produktif. Firman Allah SWT dalam surah al-Baqarah yang menyebut bahawa orang yang membelanjakan harta pada jalan Allah akan diberikan ganjaran pahala yang berlipat ganda. ${ }^{39}$

Ibn Khaldun di dalam kitab Muqaddimah telah menekankan kepentingan pelaburan dengan ungkapan:

"Dan ketahuilah bahawa harta tidak berkembang apabila disimpan dan dikumpulkan dalam peti besi. Harta hanya akan tumbuh dan berkembang apabila dibelanjakan untuk kesejahteraan rakyat, memberikan mereka hak-hak mereka, dan bagi menghapuskan kesusahan mereka."

Situasi ini seterusnya dapat mensejahterakan kehidupan rakyat, mengukuhkan kestabilan negara, mewujudkan suasana yang makmur dan meningkatkan martabat sesebuah negara..$^{40}$

Terdapat hadis sebagaimana telah diriwayatkan oleh Umar al-Khattab dan Aisyah bahawa Rasulullah SAW telah bersabda bahawa penjaga yang menguruskan harta anak yatim hendaklah memperdagangkan harta tersebut dan tidak membiarkannya habis dimakan oleh zakat. ${ }^{41}$ Hadis berkenaan merupakan sandaran yang jelas berhubung keharusan mengembangkan harta menerusi aktiviti pelaburan yang halal bagi menjana keuntungan kepada pemilik dan penerima manfaat.

38 Mohd Afandi Mat Rani et al., Transformasi Wakaf di Malaysia: Isu dan Cabaran (Shah Alam: Institut Kajian Zakat Malaysia, Universiti Teknologi Mara, t.t.), 151.

39 Al-Baqarah (2): 261.

40 Al-Baqarah (2):146.

41 'اتجروا في أموال اليتامى لا تأكلها الزكاة ', hadith yang diriwayatkan oleh Imam Malik sebagaimana yang disebutkan oleh Umar al-Khattab. Lihat Malik bin Anas, al-

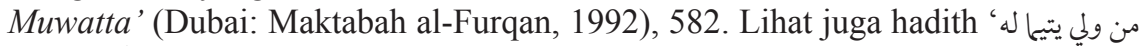

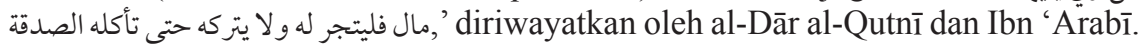
Lihat 'Alī bin 'Umar al-Dār al-Qutn̄̄, Sunan al-Dār al-Qutn̄̄, vol. 2 (Beirūt: Dār al-Ma'rifah, t.t.), 280; Ibn al-'Arabī al-Malikī, 'Aridah al-Ahwazì bi Sharh alTirmidhī, vol. 3 (Beirūt: Dār al-Kutub al-'Ilmiyyah, t.t), 136. 


\section{KONSEP PEMBANGUNAN DAN PELABURAN WAKAF SECARA LESTARI}

Pengertian wakaf daripada sudut istilah sebagaimana yang diungkapkan oleh Ibn Qudāmah, "tahbīs al-asl wa tasbīl al-thamarah" "42 yang bermaksud "menahan harta yang asal dan menyalurkan hasil" jelas menggambarkan tentang konsep wakaf sebagai suatu bentuk harta yang bersifat dinamik dan lestari. Definisi ini memberi konotasi bahawa harta wakaf adalah terdiri daripada harta yang tidak akan musnah setelah digunakan dan berupaya menjana manfaat tanpa menghabiskan 'ayn harta tersebut. Lantaran itu, harta wakaf hendaklah terdiri daripada kategori harta yang mempunyai ciri-ciri kekal di samping menghasilkan manfaat secara konsisten merangkumi harta

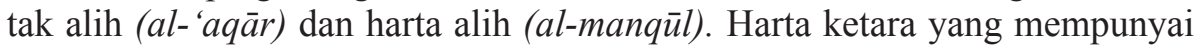
fizikal seperti tanah dan bangunan merupakan kategori harta wakaf yang popular di samping harta benda lain seperti wang tunai, buku, perabot, haiwan ternakan, kenderaan dan jentera. Manakala harta dalam bentuk kontemporari seperti saham, bon, unit amanah, manfaat, dan hak-hak berkaitan kewangan yang berupa harta intelek seperti paten, hak cipta dan cap dagangan juga telah diiktiraf sebagai harta wakaf oleh majoriti ulama. ${ }^{43}$

Menahan harta wakaf bagi menjamin kekekalan bukanlah bermaksud membiarkan harta tersebut terpendam atau dimakan lalang tanpa sebarang usaha. Penahanan harta wakaf sebenarnya merujuk kepada menahan harta daripada sebarang bentuk pemilikan individu kepada hak milik Allah SWT secara kekal, ${ }^{44}$ manakala, manfaatnya disalurkan bagi tujuan kebajikan. ${ }^{45}$ Justeru, pengertian kekal bagi harta wakaf bukan sekadar merujuk kepada mengekalkan fizikal aset semata-mata bahkan turut mengambil kira keupayaan aset wakaf menjana manfaat secara berterusan. ${ }^{46}$ Sebagai suatu bentuk pengorbanan harta yang bercirikan penjanaan manfaat secara mampan, wakaf secara tidak langsung menganjurkan konsep pelestarian aset yang efisien untuk dinikmati oleh umat Islam dahulu, kini dan masa hadapan.

42 Muwafiq al-Dīn 'Abd Allāh bin Aḥmad, Ibn Qudāmah, al-Mughnī, vol. 5 (Beirūt: Dār Ihyya' al-Turāth al-'Arabī, 1985), 375.

43 Majma Fiqh al-Duwali, Keputusan no. 175 (1/19), United Arab Emirates (UAE), 26-30 April 2009.

44 Shams al-Dīn Muhammad bin al-Khātib al-Sharbinī, Mughn̄ al-Muhtāj ila Ma 'rifati Alfāz al-Minhājj, vol. 2 (Beirūt: Dār al-Ma'rifah, 1997), 376.

45 al-Zarqa, Ahkām al-Awqā $f, 10$.

46 Monzer Kahf, 'Towards the Revival of Awqaf: A New Fiqhi Issues to Reconsider,' (Kertas kerja yang dibentangkan dalam Seminar Harvard Forum on Islamic Finance and Economics, Harvard University, U.S.A, 1 Oktober 1999), 4. 
Manakala pewakaf yang menyerahkan hartanya ke jalan Allah SWT juga akan menikmati ganjaran pahala sepanjang hayat sehingga selepas kematiannya. Ini bertepatan dengan konsep șadaqah jāriyah dalam hadis Rasulullah SAW yang merujuk wakaf sebagai suatu amalan yang menjanjikan ganjaran pahala yang berkekalan di dunia dan ke akhirat. ${ }^{47}$ Amat jelas sekali bahawa konsep wakaf itu sendiri begitu sarat dengan sentuhannya yang bersifat syumul kerana menggabungkan aspek ibadah bagi mendekatkan diri kepada Allah (taqarrub ila Allah) di samping menganjurkan elemen pembangunan material untuk kemaslahatan ummah secara lestari.

Konsep pembangunan yang bersifat lestari secara amnya telah dijelmakan menerusi konsep wakaf dalam Islam. Entiti wakaf pada dasarnya adalah bersifat "sustainable" (mampan) kerana ditadbir oleh prinsip-prinsip fundamental iaitu kekal, tidak boleh dipindah milik dan ditarik balik. ${ }^{48}$ Ciri-ciri ini menjadikan wakaf sebagai agen terbaik bagi membina aset dan kekayaan umat Islam. Sejarah ketamadunan Islam telah membuktikan bahawa wakaf memainkan peranan yang penting sebagai sektor ketiga yang meringankan beban kerajaan dalam membiayai kebajikan masyarakat. Peranan wakaf yang begitu signifikan ini telah diungkapkan oleh Yediyildiz ${ }^{49}$ dan Baskan ${ }^{50}$ berhubung dengan kepentingan wakaf pada era kegemilangan empayar Turki Uthmaniyyah bahawa kehidupan individu semenjak daripada kelahiran sehingga kematiannya dibiayai oleh institusi wakaf.

Wakaf sebagai suatu sumbangan yang berbentuk kekal abadi juga seharusnya bersifat produktif kerana menggabungkan elemen simpanan tetap serta pelaburan jangka panjang. ${ }^{51}$ Menurut Kahf, konsep wakaf menggabungkan

47 International Shariah Research Academy for Islamic Finance (ISRA), ISRA Compendium for Islamic Financial Terms: Arabic-English, 96; Muhammad M. al-Arnawut, Dawr al-Waqf fì al-Mujtami 'at al-Islāmī (Lubnan: Dār al-Fikr alMu'asir, 2000), 79.

48 Mohammad Obaidullah, 'Waqf Development: Islamic Development Bank Experience,' (Kertas kerja yang dibentangkan dalam Seminar Wakaf Kebangsaan 2014, Hotel Istana Kuala Lumpur, 7-8 Disember 2014), 1.

49 Yediyyildiz, B., 'Place of the Waqf in Turkish Cultural System,' (Kertas kerja yang dibentangkan dalam seminar Habitat II, 12 April 1996, Istanbul).

50 Birol Baskan, 'Waqaf System as a Redistribution Mechanism in Ottoman Empire,' (Kertas kerja yang dibentangkan dalam seminar 17th Middle East History and Theory Conference, Center for Middle Eastern Studies, University of Chicago, 10-11 Mei 2002), 18.

51 Mohd. Daud Bakar, 'Amalan Institusi Wakaf di beberapa Negara Islam,' dalam Konsep dan Pelaksanaan Wakaf di Malaysia, ed. Nik Mustapha Nik Hassan (Kuala Lumpur: Institut Kefahaman Islam Malaysia (IKIM), 1999), 161. 
elemen simpanan dan pelaburan melalui pengumpulan aset dan pertumbuhan modal dalam ekonomi bagi meningkatkan pengeluaran perkhidmatan dan pendapatan selaras dengan konsep pengekalan wakaf. Oleh itu, sebarang bentuk pengurangan aset wakaf adalah ditegah sama sekali malah tindakan menghabiskan harta wakaf atau meninggalkannya dalam keadaan terbiar akibat daripada kecuaian atau pencerobohan adalah dilarang dalam Islam. ${ }^{52}$

Sehubungan itu, proses pembangunan menurut definisi dan kerangka wakaf yang beroperasi menerusi aktiviti pengumpulan kekayaan melalui pelaburan secara produktif dengan objektif memberi keuntungan secara berterusan menjangkaui peredaran zaman adalah menepati konsep pembangunan secara lestari. Abdul Haseeb Ansari et al. berpendapat bahawa hakikatnya konsep pembangunan mampan telahpun terkandung dalam ajaran Islam memandangkan Allah SWT melarang umat manusia agar memelihara alam sekitar tanpa melakukan kerosakan (fasād) di atas muka bumi ini. ${ }^{53}$ Idea tentang pembangunan mampan adalah berteraskan konsep-konsep khalifah, ukhuwwah, amānah, mașlahah mursalah (kepentingan awam) dan sadd al-dharā' $i$ ' (menghalang kemungkaran). ${ }^{54}$ Interaksi yang dinamik antara proses pembinaan sosioekonomi dan keutamaan pemeliharaan alam sekitar sebenarnya juga adalah bagi menyahut tuntutan Maqāșid al-Syarī'ah. ${ }^{55}$

Mohamad Tahir berpandangan bahawa wakaf merupakan salah satu sektor yang berperanan untuk menjamin kemapanan dan kestabilan hidup manusia (human sustainability) bagi mencapai matlamat keadilan dan kesamarataan dalam sosioekonomi. ${ }^{56}$ Oleh itu, hartanah wakaf wajar mendapat pengiktirafan setanding dengan aset-aset lain dalam pasaran hartanah serta tidak dianggap sebagai aset kelas kedua daripada sudut perundangan dan kuasa pasaran bagi membolehkan harta tersebut menjana pendapatan secara berterusan dan

52 Kahf, 'Financing the Development of Awqaf Property,' 6-8.

53 Ansari, Abdul Haseeb, Jamal, Parveen \& Oseni, Umar A., 'Sustainable Development: Islamic Dimension with Special Reference to Conservation of the Environment,' Advances in Natural and Applied Sciences, 6/5 (2012): 607.

54 Ansari, Abdul Haseeb, Jamal, Parveen \& Oseni, Umar A., 'Sustainable Development: Islamic Dimension with Special Reference to Conservation of the Environment,' 607-619.

55 Ainul Jaria Maidin \& Omar Oseni, 'Islamic Principles on Sustainable Land Use Planning and Development,' Journal of Islamic Law Review, 7/1 (Jun, 2011): 6063.

56 Mohammad Tahir Sabit Mohammad, 'Sustaining the Means of Sustainability: The Need for Accepting Wakaf (Wakaf) Assets In Malaysian Property Market,' (Kertas kerja yang dibentangkan dalam Seminar the 14th Annual Conference of the Pacific Rim Real Estate Society, Kuala Lumpur, 20-23 Januari 2008), 1. 
berdikari (self-reliant). ${ }^{57}$ Peranan wakaf juga tidak sekadar dilihat sebagai sebuah institusi filantropi yang mengharapkan sumbangan dan derma daripada orang ramai. Wakaf seharusnya mempunyai keupayaan menjana pendanaan kendiri (self sustained financing) yang amat diperlukan bagi memastikan kelestarian institusi wakaf yang mampu berdiri tanpa kebergantungan kepada mana-mana sumber dana yang lain. ${ }^{58}$

Magda telah menggariskan empat objektif penubuhan wakaf iaitu sebagai suatu wadah kepada pewakaf untuk mendapatkan ganjaran yang berterusan; memenuhi keperluan benefisiari; menyediakan peluang pekerjaan kepada orang awam dan memastikan harta wakaf kekal. ${ }^{59}$ Justeru, umat Islam harus bertindak secara kreatif dan inovatif bagi mentransformasikan peranan wakaf menerusi kaedah pembangunan dan pelaburan yang efisien bagi membolehkan aset wakaf menjana pendapatan kendiri secara berterusan. Walau bagaimanapun, realitinya di Malaysia, sehingga ke hari ini masih terdapat banyak harta wakaf yang belum dimajukan secara dinamik berikutan ketiadaan sumber dana yang mencukupi untuk membangunkan aset-aset wakaf yang terbiar dan terpendam.

Walau seindah mana pun pandangan yang diutarakan oleh para cendekiawan Islam bagi menerangkan tentang konsep pembangunan, ia tidak dapat dilaksanakan tanpa mempunyai sumber dana yang mencukupi. Di samping itu, bilangan dan kuantiti harta wakaf yang masih banyak dan belum dimajukan ${ }^{60}$ boleh menimbulkan tanda tanya daripada sudut sama ada harta tersebut sudah menepati konsep wakaf yang sebenar kerana dikhuatiri harta-harta tersebut sekadar kekal daripada sudut ain dan fizikalnya sahaja tetapi masih belum menjana hasil untuk dimanfaatkan oleh benefisiari wakaf. Situasi ini bukan sahaja menafikan hasrat pewakaf untuk mendapat ganjaran pahala yang berterusan bahkan meletakkan harta wakaf dalam status beku sehingga boleh membawa kepada pembaziran dan kemudaratan daripada sudut ekonomi yang merugikan umat Islam.

57 Mohammad Tahir Sabit Mohammad, 'Sustaining the Means of Sustainability: The Need for Accepting Wakaf (Wakaf) Assets In Malaysian Property Market,' 1.

58 Jabatan Wakaf Zakat dan Haji, 'Rumusan dan Resolusi,' (Seminar Waqaf Antarabangsa 2014, Hotel Istana Kuala Lumpur, 8-10 Disember 2014).

59 Magda Ismail, 'What We Can Do with Waqf Properties,' (Kertas kerja yang dibentangkan dalam Roundtable Discusssion on Development Waqf Properties in Malaysia, Sasana Kijang, Bank Negara Malaysia, Kuala Lumpur, 21 Januari 2014).

60 Ashfaque Ali, 'Socio-Economic Role of Awqaf in the Advancement of Muslims,' Awqaf, 3 (2002): 21-30. 


\section{KEPENTINGAN PELABURAN BAGI INSTITUSI WAKAF}

Wakaf secara amnya merupakan sebuah organisasi tidak bermotifkan keuntungan (non-profit organisation/NPO) yang berperanan dalam menyalurkan kemudahan berkaitan keagamaan dan kebajikan sosial kepada masyarakat. Organisasi tidak bermotifkan keuntungan seperti wakaf mempunyai matlamat penubuhan yang khusus dan mempunyai kaitan dengan kemaslahatan awam misalnya dalam bidang keagamaan, sains dan teknologi, pendidikan, kebudayaan, kesihatan, pekerjaan, perhubungan awam, sukan, dan perlindungan alam sekitar. ${ }^{61}$ Bryce telah menggariskan empat konsep asas dalam menjayakan sesebuah organisasi tidak bermotifkan keuntungan iaitu misi, wang, pemasaran dan pengurusan. Bryce berpendapat bahawa tanpa sumber kewangan, apa jua misi dan matlamat NPO tidak akan dapat dicapai dan diketengahkan dalam ekonomi pasaran, walau sebaik mana atau sebanyak mana usaha kebajikan dilaksanakan oleh organisasi tersebut. ${ }^{62}$

Kebanyakan NPO amat bergantung kepada sumbangan daripada orang ramai sebagai sumber pendanaan bagi menghidupkan organisasi mereka menyalurkan perkhidmatan sosial kepada masyarakat. Sumber kewangan utama organisasi-organisasi ini umumnya berupa geran daripada kerajaan dan sumbangan individu persendirian khusus untuk menampung kos operasi. ${ }^{63}$ Dalam konteks wakaf, di samping sumbangan sesuatu aset secara langsung, sumbangan orang ramai menerusi wakaf tunai dan saham wakaf merupakan antara mekanisme yang telah dikenal pasti berupaya untuk membiayai pembangunan wakaf. Walau bagaimanapun, jumlah hasil kutipan wakaf tunai dan saham wakaf di kebanyakan negeri di Malaysia masih belum mencukupi untuk membangunkan projek wakaf berskala besar, justeru menyebabkan

${ }_{61}$ Nor Sharina Mohd Rafien et al., 'Not-For-Profit Religious Organization in Malaysia: A Case on Zakat Institution,' dalam Islamic Philanthropy For Ummah Excellence, ed. Noraini Mohamad et al. (Kuala Lumpur: Institute Kajian Zakat Malaysia, Universiti Teknologi MARA), 239.

62 Empat konsep asas tersebut dirumuskan sebagai $4 M s$ iaitu "mission" (misi), "money" (wang), "marketing" (pemasaran) dan "management" (pengurusan). Manakala bagi persatuan atau koperasi elemen kelima yang penting ialah "membership" (keahlian). Lihat Bryce, Herrington J, Financial \& Strategic Management for Nonprofit Organizations, A Comprehensive Reference to Legal, Financial, Management and Operations Rules and Guidelines for Nonprofits, $3^{\text {rd }}$ ed. (San Francisco: Jossey-Bass, 2000), 3-4.

63 Brown L. D., \& Mark H. M., 'Accountability, Strategy and International NonGovernmental Organizations. The Hauser Center for Nonprofit Organizations,' (The Kennedy School, Harvard University, 2001), 13. 
kebanyakan Majlis Agama Islam Negeri (MAIN) masih mengharapkan bantuan dana daripada kerajaan Persekutuan untuk membangunkan aset wakaf.

Pada dasarnya, peranan NPO seperti institusi wakaf yang bermatlamatkan kebajikan sosial tetapi perlu menghasilkan output sebagai sebuah institusi bersifat komersial sering dipersoalkan dari segi bagaimana kedua-dua elemen sosial dan keuntungan (komersial) ini dapat diharmonikan? Bagi menjawab keraguan dan persoalan ini, Cizakca berpendapat bahawa sejarah telah membuktikan wakaf telah pun berperanan sebagai sebuah institusi pengumpulan dan pengagihan kekayaan umat Islam semenjak beratus tahun yang lampau. ${ }^{64}$ Sehubungan itu, umat Islam sewajarnya menyahut cabaran tersebut bagi menyemarakkan peranan wakaf agar dapat berdiri sama tinggi dengan sektor komersial serta setanding dengan institusi korporat yang mempunyai jangka hayat yang panjang. ${ }^{65}$ Hasilnya, institusi wakaf akan berupaya meluaskan lagi aspek penyampaian perkhidmatan kebajikan secara lebih efektif kepada umat Islam.

Sejajar dengan perkembangan sistem kewangan Islam yang semakin pesat, peluang ini sewajarnya dimanfaatkan oleh institusi wakaf untuk mengaplikasikan strategi pembangunan dan pelaburan secara kreatif dan inovatif seiring dengan keperluan dan tuntutan semasa. Realitinya, Malaysia boleh dianggap sebagai sebuah negara yang pemurah kerana pihak kerajaan begitu komited memperuntukkan sebahagian daripada perbelanjaan negara bagi tujuan pembangunan institusi berkaitan keagamaan seperti wakaf menerusi peruntukan perbelanjaan pembangunan dalam usaha memajukan harta wakaf sebanyak RM256.4 juta dalam Rancangan Malaysia Kesembilan (RMK-9) dan peruntukan tambahan berjumlah RM109.4 juta dalam Rancangan Malaysia Kesepuluh (RMK-10) bagi tujuan merealisasikan 17 projek pembangunan wakaf di seluruh negara. ${ }^{66}$

Keadaan ini jauh berbeza sekali dengan kebanyakan negara yang mempunyai penduduk Islam minoriti seperti Singapura yang mana Majlis Agama Islam Singapura (MUIS) selaku mutawallī yang begitu proaktif

${ }_{64}$ Murat Cizacka, 'The Waqf, Its Contribution and Basic Operational Structure,' (Kertas Seminar Waqf Redefining Prosperity and Growth, International Centre for Education in Islamic Finance (INCEIF), Kuala Lumpur, 15 Disember 2011).

65 Kahf, 'Financing the Development of Awqaf Property,' 6.

66 Projek-projek tersebut melibatkan pembinaan asrama anak yatim, premis niaga, pusat kegiatan saudara baru, pusat hemodialisis, pusat perlindungan wanita, hotel dan kompleks pendidikan. Lihat Anan C. Mohd, 'Pembangunan WakafPengalaman Malaysia,' (Kertas kerja yang dibentangkan dalam Seminar Wakaf Serantau di Hotel Sunway Putra, Kuala Lumpur, 4-5 September 2012). 
merencana pelbagai pendekatan bagi membangunkan aset hartanah wakaf agar setanding dengan arus pembangunan ekonomi di Singapura. ${ }^{67}$ Senario ini secara tidak langsung telah mendorong MUIS untuk mengaplikasikan pelbagai mekanisme pembangunan menggabungkan kaedah klasik seperti istibdāl dan $h u k r$ (sewa jangka panjang) dengan instrumen kewangan kontemporari seperti sukuk mushārakah bagi memajukan hartanah wakaf. Menerusi mekanisme pembangunan dan pelaburan hartanah yang bersepadu, MUIS telah berjaya melakukan inisiatif menaik taraf dan menyerlahkan nilai (unlock the value) sebenar aset-aset wakaf di Singapura yang dahulunya terdiri daripada aset yang kurang berkualiti. Aset hartanah wakaf di Singapura kini terdiri daripada rangkaian aset berkualiti dan berpendapatan tinggi di samping memberi pulangan pelaburan dalam bentuk penjanaan pendapatan yang lebih lumayan dan konsisten kepada benefisiari wakaf. ${ }^{68}$

Mekanisme pembangunan wakaf terbahagi kepada kaedah tradisional dan moden. Kaedah tradisional merangkumi kaedah seperti istibdāl dan ijārah manakala kaedah kontemporari melibatkan aplikasi instrumen kewangan seperti penerbitan sukuk, akad built operate and transfer (BOT), jointventure (JV) serta gabungan kaedah tradisional dan kontemporari. Hasilnya, beberapa bangunan pencakar langit seperti Zam Zam Tower di kota suci Mekah dan Menara Imarah Wakaf di Kuala Lumpur telah menjadi ikon wakaf yang bercirikan filantropi dan komersial sebagai mercu tanda kedinamikan peradaban Islam yang berkekalan sepanjang zaman.

Di samping itu, perhatian juga harus diberikan terhadap mekanisme pembangunan dan pelaburan jangka panjang yang lain bagi mengoptimumkan penggemblengan aset wakaf secara kendiri (selfsustained) tanpa mengharapkan bantuan dana yang lain menerusi kaedah pelaburan yang strategik. Pendekatan ini bagi menjamin pengekalan modal wakaf (principal amount) di samping menjana pulangan dividen yang stabil dan berterusan kepada benefisiari wakaf. Transformasi menyeluruh ini perlu dilakukan dalam pengurusan dan pentadbiran wakaf bagi menangani setiap isu dan cabaran yang dihadapi serta menjadikan wakaf sebagai model pembangunan ekonomi untuk melestarikan pembangunan sosioekonomi ummah.

\footnotetext{
67 Shamsiah Abdul Karim (Penolong Pengarah, Bahagian Wakaf, Majlis Agama Islam Singapura), dalam temu bual beliau bersama penulis, pada 30 April 2012.

68 Shamsiah Abdul Karim, 'Contemporary Shari'a Compliance Structuring for the Development and Management of Waqf Assets in Singapore,' Kyoto Bulletin of Islamic Area Studies, 3/2 (March 2010): 143-164.
} 


\section{SENARIO PELABURAN WAKAF}

Sebahagian besar aset wakaf di Malaysia adalah terdiri daripada aset hartanah manakala hanya sebahagian kecil berupa wang tunai. Di negeri Selangor misalnya, bagi tahun 2014, 97\% daripada aset wakaf di negeri berkenaan terdiri daripada aset hartanah manakala 3\% dalam bentuk wang tunai dengan anggaran aset hartanah bernilai RM134 juta manakala aset tunai berjumlah RM5 juta. ${ }^{69}$ Manakala di Singapura, 95\% daripada keseluruhan aset di negara tersebut adalah dalam bentuk hartanah manakala selebihnya adalah dalam bentuk wakaf tunai yang dilaburkan dalam pelbagai instrumen kewangan seperti deposit jangka pendek dan bon. ${ }^{70}$ Setakat bulan Disember 2014, nilai aset hartanah wakaf di Malaysia dianggarkan bernilai RM1 bilion dengan jumlah keluasan tanah wakaf berjumlah 11,000 hektar. ${ }^{71}$ Walau bagaimanapun, tiada data komprehensif yang diperoleh bagi menyokong nilai atau anggaran kasar jumlah wakaf tunai di negara ini berikutan pengurusan dan pentadbiran wakaf adalah terletak pada 13 negeri yang berbeza.

Tinjauan penulis mendapati bahawa kebanyakan MAIN kurang terdedah kepada aspek pengurusan pelaburan dana wakaf secara efisien apabila dana yang terkumpul menerusi wakaf tunai atau saham wakaf rata-ratanya hanya disimpan di dalam akaun simpanan atau simpanan tetap Islam bertempoh dengan pulangan sekitar tiga peratus. ${ }^{72}$ Ini berikutan terdapat kekhuatiran di pihak MAIN tentang kemungkinan wang tersebut mengalami kerugian

69 Setakat bulan Oktober 2014, Abu Bakar Yang, 'Pembangunan Wakaf (Perbadanan Wakaf Negeri Selangor)' (Kertas kerja yang dibentangkan dalam Seminar Waqaf Antarabangsa 2014, Hotel Istana Kuala Lumpur, 8-10 Disember 2014).

70 Shamsiah Abdul Karim, 'Contemporary Shari'ah Structuring for the Development and Management of Waqf Assets in Singapore,' (Tesis Ijazah Doktor Falsafah, Durham University, 2010), 40.

71 Anan C. Mohd, 'Senario Pembangunan Waqf di Malaysia: Waqaf Melestarikan Pembangunan Ummah,' (Kertas kerja Seminar Antarabangsa 2014, 7-10 Disember 2014), 13.

72 Mustapa Hayuddin Abdul Halim (Penolong Pengarah Wakaf, Pejabat Wakaf, MAIN Agama Islam Johor), dalam temu bual beliau dengan penulis, pada 26 September 2013; Fakhruddin Abd Rahman (Ketua Bahagian Wakaf, Majlis Agama Islam Pulau Pinang), dalam temu bual beliau dengan penulis, pada 17 Julai 2014; Abdul Wahab Othman (Penolong Pengurus Hartanah, Bahagian Pembangunan dan Pelaburan Majlis Agama Islam Wilayah Persekutuan Kuala Lumpur), dalam temu bual beliau dengan penulis, pada 5 September 2014; Hamizah Jais (Penolong Eksekutif Kewangan, Perbadanan Wakaf Selangor), dalam temu bual beliau dengan penulis, pada 16 Oktober 2014. 
sekiranya dilaburkan dalam segmen ekuiti yang lebih berisiko. Sementara itu, hasil dapatan kajian oleh Cizakca membuktikan bahawa lebih daripada 20\% wakaf tunai yang wujud semasa era Empayar Turki Uthmaniyyah terus kekal selama lebih 100 tahun. $^{73}$ Senario ini jelas membuktikan bahawa aset wakaf dalam bentuk harta alih seperti wang tunai berupaya dipertahankan daripada sudut kecekalannya meskipun tidak mempunyai jasad sekiranya diuruskan secara cekap.

Pendekatan ini adalah berbeza dengan inisiatif yang diambil oleh beberapa institusi wakaf di negara-negara seperti Kuwait ${ }^{74}$ dan Singapura ${ }^{75}$ termasuk beberapa endowmen ${ }^{76}$ pendidikan di luar negara seperti Harvard Endowment ${ }^{77}$ dan Yale Endowment ${ }^{78}$ yang melaksanakan strategi pelaburan bersifat dinamik bagi menjana pendapatan yang konsisten kepada institusi terbabit.

Pada dasarnya wakaf dan endowmen merupakan dua entiti filantropi yang mempunyai ciri-ciri yang hampir sama iaitu pemberian yang berkekalan dan hanya manfaatnya diagihkan kepada benefisiari yang tertentu. Walau bagaimanapun, para sarjana yang membahaskan kedua-dua konsep ini telah menggariskan perbezaan yang ketara antara kedua-duanya. Wakaf secara amnya merupakan suatu bentu pemberian berkekalan atau șadaqah jāriyah yang lahir daripada ruh dan tasawwur Islam yang bertunjangkan kepada dalil al-Quran, al-Sunnah serta ijmā' fuqaha. Manakala sistem endowmen lahir daripada konsep trust dalam perundangan Inggeris yang tidak bersumberkan

73 Cizakca, Murat, A History of Philanthropic Foundations, The Islamic World From the Seventh Century to the Present, 52.

74 Al-Busharah, Khaled M., 'Kuwait Awqaf Public Foundation, (KAPF), Developmental Social Experience and Prospects,' (Kertas kerja yang dibentangkan dalam The Arab Forum Towards A New Welfare Mix: Rethinking the Role of the State, Market and Civil Society in the Provision of Basic Social Services, Beirut, 19-20 Disember 2012).

75 Shamsiah Abdul Karim, 'Contemporary Investment and Development of Waqf Assets in Singapore,' (Kertas kerja yang dibentangkan dalam International Islamic Capital Market Forum, Sasana Kijang Kuala Lumpur, 20 September 2012).

76 Endowmen ialah pemberian yang berkekalan dalam bentuk wang atau harta yang lain yang didedikasikan bagi tujuan tertentu. Kebanyakan endowmen ditubuhkan bertujuan mengekalkan jumlah modal yang asal dan pada masa yang sama menggunakan hasil pelaburan dalam bentuk dividen bagi tujuan kebajikan. Lihat investopedia http://www.investopedia.com/terms/e/endowment.asp, 6 September 2014.

77 Harvard Management Company Endowment Report 2013.

78 Yale Endowment 2013. 
nilai atau ruh yang bersifat keagamaan meskipun mempunyai elemen yang berteraskan kebajikan.

Daripada sudut pemilikan, aset wakaf dimiliki oleh pemilik asal iaitu Allah SWT dan mutawallī atau pemegang amanah dilantik untuk menguruskan aset wakaf sebaliknya bagi sesuatu endowmen, pemegang amanah merupakan pemilik kepada sesuatu endowmen atau trust. Dari segi harta atau objek yang boleh diinfakkan pula, hanya harta yang halal sahaja yang sah untuk diwakafkan manakala perundangan endowmen atau trust tidak menetapkan sedemikian yang mana aset yang mempunyai elemen riba juga boleh disalurkan kepada endowmen. Ini bermakna aset wakaf hanya boleh dikembangkan atau dilaburkan dalam perniagaan yang halal tanpa unsur-unsur batil seperti riba manakala harta endowmen boleh dilaburkan dalam perniagaan yang bercirikan faedah atau riba bagi menjamin pulangan yang tinggi dan konsisten kepada endowmen tersebut.

Di Amerika Syarikat misalnya, yayasan atau institusi endowmen di negara berkenaan meletakkan sasaran keuntungan pelaburan sebanyak sembilan peratus 9\% setahun bagi memenuhi keperluan untuk membuat agihan bagi tujuan kebajikan serta menanggung kos pengurusan. ${ }^{79}$ Rata-ratanya kebanyakan institusi endowmen terkemuka ini mencatatkan keuntungan dalam segmen pelaburan yang agak tinggi setiap tahun hasil daripada kecekapan dalam pengurusan portfolio pelaburan. Sebagai contoh, Harvard Endowment mencatatkan pulangan pelaburan sebanyak $15.4 \%$ bagi tahun fiskal setakat 30 Jun 2014 dengan nilai keseluruhan endowmen berkenaan ialah USD36.4 bilion $^{80}$ manakala Yale Endowment mencatatkan pulangan pelaburan tertinggi dalam tempoh 10 tahun iaitu sebanyak $20.2 \%$ dengan saiz endowmen bernilai USD23.9 bilion. ${ }^{81}$ Data ini membuktikan bahawa strategi pelaburan yang efisien dan progresif memainkan peranan yang penting bagi menjana pendapatan yang stabil kepada institusi-institusi endowmen ke arah meningkatkan agihan kepada benefisiari.

Rajah 1 menunjukkan perbandingan portfolio pelaburan bagi empat institusi wakaf dan endowmen. Berdasarkan perbandingan, 79\% aset wakaf di Singapura dilaburkan dalam segmen hartanah, 5\% dalam ekuiti atau sukuk

\footnotetext{
79 Tunku Alina, 'Unleashing the Potential of the Waqf As an Economic Institution in Malaysia: Policy, Legal and Economic Reforms,' 265.

80 Harvard Management Company, 'Message from CEO,' Annual Endowment Report (September 2014), 1.

81 Yale University Investment Office 2014, http://investments.yale.edu/, diakses pada 11 Disember 2014.
} 
dan selebihnya 16 peratus $16 \%$ merupakan pelaburan dalam perniagaan. ${ }^{82}$ Manakala bagi Kuwait Awqaf Public Foundation (KAPF), 53\% meliputi pelaburan dalam sektor hartanah, 41\%dalam sektor kewangan dan 6\% dalam sektor perkhidmatan. ${ }^{83}$ Di samping itu, KAPF juga mempraktikkan strategi pelaburan merentasi sempadan geografi apabila 13 peratus daripada aset wakaf yayasan berkenaan berada di Eropah, Amerika, Negara-Negara Teluk dan beberapa negara lain. ${ }^{84}$

Perbandingan data portfolio pelaburan antara Yale Endowment dan Harvard Endowment berasaskan kelas aset (asset classes) menunjukkan bahawa sebahagian besar pelaburan kedua-dua endowmen ini adalah dalam ekuiti iaitu 49\% bagi Harvard Endowmen dan 48\% bagi Yale Endowmen. Manakala selebihnya dilaburkan dalam pelbagai aset kelas lain seperti pulangan pasti (absolute return), ${ }^{85}$ simpanan tetap, aset sebenar (real asset) merangkumi komoditi, sumber semula jadi ${ }^{86}$ dan hartanah serta wang tunai.

Rajah 1: Perbandingan Portfolio Pelaburan

\begin{tabular}{lcccccc}
\hline Institusi & $\begin{array}{c}\text { Aset Sebenar } \\
\text { (Hartanah/ } \\
\text { Komoditi) } \\
\%\end{array}$ & $\begin{array}{c}\text { Ekuiti } \\
\text { (Tempatan/ } \\
\text { Luar Swasta) } \\
\%\end{array}$ & $\begin{array}{c}\text { Pendapatan } \\
\text { Tetap } \\
\text { (Bon/Sukuk) } \\
\%\end{array}$ & $\begin{array}{c}\text { Pulangan } \\
\text { Pasti } \\
\text { Absolute } \\
\text { Return }) \\
\%\end{array}$ & $\begin{array}{c}\text { Tunai } \\
\%\end{array}$ & $\begin{array}{c}\text { Bisnes/ } \\
\text { Servis/ } \\
\text { Lain-Lain }\end{array}$ \\
\hline MUIS & 79 & 5 & & - & & 16 \\
KAPF & 53 & 41 & & - & - & 6 \\
Harvard & 25 & 49 & 9 & 15 & $0 / 2$ & - \\
Endowment & 27 & 48 & 5 & 18 & $2 / 0$ & - \\
Yale Endowment & 27 & & & & & - \\
\hline
\end{tabular}

Sumber: MUIS, KAPF, Harvard Endowment dan Yale Endowment.

82 Shamsiah Abdul Karim, 'Contemporary Investment and Development of Waqf Assets in Singapore,' (International Islamic Capital Market Forum, Sasana Kijang, Kuala Lumpur, 20 September 2012).

83 Al-Busharah, Khaled M., 'Kuwait Awqaf Public Foundation, (KAPF), Developmental Social Experience and Prospects,' 7.

84 Al-Busharah, Khaled M., 'Kuwait Awqaf Public Foundation, (KAPF), Developmental Social Experience and Prospects,' 7.

85 'Absolute return investment techniques include using short selling, futures, options, derivatives, arbitrage, leverage and unconventional assets', lihat http:// www.investopedia.com/terms/a/absolutereturn.asp, diakses pada 13 Disember 2012.

86 'Including oil and gas investing, precious metals investing, minerals and (base) metals investing and so on', lihat http://www.investopedia.com/articles/basics/12/ natural-resource-investing.asp, diakses pada 13 Disember 2012. 
Pada dasarnya, kebanyakan endowmen telah mengambil pendekatan membuat pelaburan dalam aset kelas yang lebih sofistikated dan berorientasikan ekuiti bagi meningkatkan hasil pelaburan mereka. Polisi pelaburan ini telah dipraktikkan oleh Yale Endowment yang mana 95\% peratus pelaburannya tertumpu pada aset yang mempunyai jangkaan menghasilkan pulangan seperti ekuiti (assets expected to produce equity-like returns) yang memberikan pulangan yang stabil kepada endowmen berkenaan. ${ }^{87}$

Jelas sekali bahawa modus operandi institusi endowmen yang pada asalnya adalah terdiri daripada harta kekal seperti hartanah sebagai aset utama kini telah beralih dengan memberi tumpuan kepada penguasaan aset dalam bentuk ekuiti bagi menjana pulangan yang lebih kompetitif. ${ }^{88}$ Di samping itu, peralihan pendekatan pelaburan oleh kebanyakan endowmen luar negara dalam aset kelas "non-traditional" seperti ekuiti swasta (private equity) juga merupakan suatu kaedah pelaburan yang popular. Pelaburan dalam segmen ekuiti swasta merujuk kepada pelaburan dalam syarikat persendirian yang tidak disenaraikan di bursa saham justeru lazimnya mempunyai saiz yang lebih kecil serta kurang birokrasi daripada segi pengurusan berbanding dengan syarikat yang tersenarai di bursa seperti seperti Toys ' $R$ ' Us, Burger King, Elizabeth Arden dan The Gap. ${ }^{89}$ Bagi Yale Endowment, 32\% daripada aset kelasnya adalah terdiri daripada pelaburan dalam ekuiti swasta dan selama 20 tahun penubuhannya semenjak tahun 1973 hingga 2013, segmen berkenaan telah menyumbang pendapatan tahunan pada kadar purata $29.9 \%$ \% ${ }^{90}$ Selain pelaburan ekuiti swasta, kebanyakan endowmen, yayasan dan pelabur institusi di Amerika Syarikat juga telah beralih kepada kelas aset "alternatif" seperti aset sebenar (real assets) meliputi komoditi, logam, hartanah dan petroleum dan dana lindung nilai (hedge funds) sebagai segmen pelaburan utama. ${ }^{91}$

Pelaburan dalam ekuiti swasta adalah berbeza dengan pelaburan menerusi konsep modal teroka (venture capital) yang mana pelaburan ekuiti swasta memberi fokus terhadap syarikat yang sudah pun mempunyai bukti menjana keuntungan menerusi pengeluaran produk dan perkhidmatan dengan

\footnotetext{
87 Yale Endowment 2013, 6.

88 Pada tahun 2013, jumlah aset hartanah dalam segmen pelaburan Harvard Endowment dan Yale Endowment masing-masing adalah sebanyak 10 peratus dan 20 peratus. Lihat Harvard Endowment 2013, 12; Yale Endowmnet 2013, 2.

89 Wildermuth, Daniel, How the Smart Money Invests. Wise Money. Using Endowment Investment Approcah to Minimize Volatility and Increase Output (New York: Mc Graw Hill, 2012), 151.

90 Yale Endowment 2013, 12.

91 Yale Endowment 2013, 10.
} 
kedudukan yang kukuh dalam pasaran. Justeru pelaburan yang dibuat adalah bagi meningkatkan dan memberi nilai tambah bagi mengukuhkan prestasi sedia ada. Berbanding dengan konsep modal teroka yang lazimnya melibatkan pelaburan dalam syarikat yang sejarah pengurusan yang terbatas serta belum terbukti daripada sudut kedudukan prestasinya dalam pasaran tetapi mempamerkan konsep bisnes yang menarik. ${ }^{92}$

Menurut Jim Garland, dalam konteks pelaburan yang melibatkan pengekalan modal seperti aset wakaf, apa yang lebih penting adalah pendapatan dan bukannya kenaikan modal bagi memenuhi keperluan benefisiari. ${ }^{93}$ Amat rugi sekali sekiranya dana wakaf yang terkumpul tidak dilaburkan secara cekap kerana wakaf wang tunai yang disimpan di dalam akaun simpanan semata-mata terdedah kepada risiko inflasi yang akan memberi kesan terhadap nilai yang disimpan untuk jangka masa panjang. ${ }^{94}$ Strategi utama pelaburan sebenarnya bukanlah sekadar mengekalkan jumlah modal yang asal sebaliknya perlu mengambil kira kuasa beli wang tunai pada masa hadapan..$^{95}$ Aspek pengurusan risiko juga perlu diberikan perhatian bagi memastikan modal wakaf terus kekal dan hanya keuntungan yang diperoleh daripada pelaburan harta wakaf akan diagihkan kepada benefisiari. Namun begitu, apabila sesuatu aset wakaf dilaburkan dalam kelas aset sebegini, penelitian dan tumpuan hendaklah diberikan terhadap aspek pengekalan modal wakaf. Oleh itu, pengurusan pengimbangan semula portfolio (portfolio rebalancing) dan pengurusan aktif (active management) amatlah penting demi memastikan kelestarian modal wakaf secara keseluruhan

Umat Islam di Malaysia juga kurang membudayakan amalan berwakaf dalam kehidupan mereka berkemungkinan disebabkan oleh stigma bahawa golongan berada dan berkemampuan yang memiliki aset hartanah yang banyak sahaja yang mampu berwakaf di samping kurang berkeyakinan terhadap aspek pengurusan wakaf kerana bimbang berlakunya ketirisan serta tidak menampakkan hasil daripada perwakafan yang telah dibuat. ${ }^{96}$ Amalan berwakaf

92 Wildermuth, How the Smart Money Invests. Wise Money. Using Endowment Investment Approcah to Minimize Volatility and Increase Output, 151-152.

93 Nuffield F.I.S, 'Endowments, Volatility and Time,' (Nuffield Foundation Investment Seminar, 5 March 2007), 7.

94 Wildermuth, How the Smart Money Invests. Wise Money. Using Endowment Investment Approcah to Minimize Volatility and Increase Output, 57.

95 Wildermuth, How the Smart Money Invests. Wise Money. Using Endowment Investment Approcah to Minimize Volatility and Increase Output, 57.

96 Noraini Md Top, 'Mobilisation of Waqf Resources in Malaysia: Problems and Prospects,' (Disertasi Ijazah Sarjana, Universiti Islam Antarabangsa Malaysia, 1991), 2. 
di negara ini bukan sahaja kurang diberikan perhatian oleh masyarakat awam malah kurang mendapat sokongan dan penyertaan daripada institusi korporat.

\section{STRATEGI PELABURAN HARTA WAKAF SECARA LESTARI MENURUT PERSPEKTIF ISLAM}

Hukum-hukum berkaitan wakaf adalah termasuk dalam perkara ijtihädiyyah yang terbuka kepada pandangan-pandangan yang lebih segar dan baharu selaras dengan keperluan dan tuntunan semasa ke arah memakmurkan institusi wakaf. Amalan pelaburan harta wakaf khususnya wakaf tunai adalah diharuskan berdasarkan pandangan daripada Imam Zufar dalam mazhab Hanafi yang membenarkan aplikasi wakaf tunai dengan melaburkannya dalam perniagaan mudāarabah dan hasilnya diagihkan untuk tujuan kebajikan. ${ }^{97}$ Manakala Imam Malik di dalam kitab al-Mudawwanah telah memberikan pandangan yang mengharuskan wakaf wang tunai menerusi mekanisme pembiayaan secara qard hasan(pinjaman tanpa faedah) dengan memberi pinjaman 100 dinar kepada orang yang ingin menjalankan perniagaan untuk tempoh masa tertentu yang mana sekiranya berlaku kerugian, peminjam dikehendaki menanggung kerugian tersebut. ${ }^{98}$ Wakaf tunai berasaskan pemberian pinjaman tanpa faedah (salaf) kepada golongan yang memerlukan turut diterima oleh ulama-ulama dalam mazhab Maliki. ${ }^{99}$ Hal ini jelas membuktikan bahawa aset wakaf sama ada dalam bentuk hartanah atau wang tunai bukanlah terdiri daripada harta yang terpendam bahkan wajar dilaburkan dan hasilnya disalurkan untuk kebajikan.

Terdapat tiga kriteria penting yang perlu diberikan perhatian dalam menguruskan pelaburan wakaf iaitu pertama, modal wakaf tidak berkurangan, justeru perlindungan terhadap modal hendaklah dijadikan prioriti; kedua, pelaburan yang dilaksanakan hendaklah berupaya menjana pendapatan yang konsisten dan stabil untuk diagihkan kepada benefisiari wakaf di samping pada masa yang sama membolehkan pewakaf mendapat ganjaran pahala

97 Muhammad Amin Ibn 'Abidīn, Radd al-Mukhtār 'ala Dur al-Mukhtār Sharh Tanwīr al-Abṣār, vol. 6 (Riyāḍ: Dār al-'Alim al-Kutub, 2003), 556; Ibn al-Humam, Sharh Fath al-Qādir, vol. 6 (Beirūt: Dār al-Kutub al-'Ilmiyyah), 203; Burhān alDīn Ibrāhim bin Mūșā bin Abī Bakr Ibn al-Shaykh 'Alī al-Tarabulsī, al-Is 'af fì al-Ahkēm al-Awqāf (Mesir: Matba'ah Hindiyyah, 1902), 25.

98 Al-Imam Malik bin Anas, al-Mudawwanah al-Kubrā, vol. 4 (Beirūt: Dār al-Kutub al-'Ilmiyyah, t.t.), 452 .

99 Al-Abiy al-Alzariy, Șālị̣ 'Abd al-Sami', Jawāhir al-Iklīl fì Madhhab al-Imām Malik, vol. 2 (Qāhirah: 'İsā al-Bābī al-Ḥalābī, 1970), 205. 
seperti yang diharapkan daripada Allah SWT secara berterusan; ${ }^{100}$ dan ketiga, pelaburan yang dibuat hendaklah patuh Syariah. ${ }^{101}$

Di samping itu, KAPF turut menekankan beberapa kriteria dalam strategi pelaburan aset-aset wakaf yang diuruskan olehnya antaranya ialah mengambil kira aspek pematuhan prinsip-prinsip Syariah, kajian terhadap prestasi ekonomi, diversifikasi pelaburan berasaskan kepada kedudukan geografi, diversifikasi instrumen pelaburan dan sektor pelaburan (kewangan, hartanah dan perkhidmatan). ${ }^{102}$ Selain itu, mempelbagaikan pilihan pelaburan merupakan antara pendekatan yang penting bagi menanggapi risiko bertepatan dengan pepatah yang sinonim dalam dunia pelaburan iaitu "Don't put your eggs in one basket." 103 Pempelbagaian pelaburan bertujuan memastikan bahawa pelabur masih lagi berpeluang untuk mendapatkan pulangan melalui satu segmen pelaburan sekiranya terdapat pulangan pelaburan lain yang kurang memuaskan atau mengalami kerugian. ${ }^{104}$ Dengan cara ini risiko pelaburan dapat dikurangkan dan berupaya memaksimumkan keuntungan.

Sementara itu, Majma' Fiqh dalam keputusan berkaitan pelaburan wakaf pada tahun 2004 menggariskan beberapa kriteria penting bagi mengembangkan aset wakaf secara produktif antaranya adalah seperti berikut: pelaburan hendaklah dilaksanakan dalam segmen pelaburan yang mematuhi prinsip-prinsip Syariah; mengekalkan modal wakaf dan pada masa yang sama menjana manfaat yang berterusan; mempelbagaikan portfolio pelaburan bagi mengurangkan risiko kerugian dan mengambil pelbagai pendekatan jaminan modal wakaf bagi mengelakkan modal wakaf merosot atau hilang; melaksanakan kajian yang komprehensif sebelum melabur bagi memastikan projek yang bakal dibiayai mempunyai potensi yang kukuh daripada

100 Abbas, Abdelraman B.M., The Economics of Benevolence: An Islamic Paradigm, (Tesis Ijazah Doktor Falsafah, University of Wales, 1990), 123-128.

101 Asyraf Wajdi Dusuki (eds.), Islamic Financial System: Principles and Operations (Kuala Lumpur: International Shari'ah Research Academy for Islamic Finance, 2011), 452-453.

102 Al-Busharah, Khaled M., 'Kuwait Awqaf Public Foundation, (KAPF), Developmental Social Experience and Prospects,' 6.

103 Ia bermaksud jangan meletakkan telur-telur di dalam satu raga bagi mengelakkan kehilangan kesemua telur tersebut sekiranya berlaku sesuatu yang tidak diingini merujuk kepada aspek keperluan mempelbagaikan segmen pelaburan bagi mengurangkan risiko kerugian dengan hanya bergantung pada satu bentuk pelaburan.

104 Securities Industry Development Corporation (SIDC), Soal Jawab Pelabur, Langkah Permulaan Pelaburan (Kuala Lumpur: SIDC, 2009), 10. 
segi keberhasilan dan impak daripada sudut ekonomi; memilih kaedah pelaburan yang selamat dan mengelakkan pelaburan yang berisiko tinggi; kaedah pelaburan hendaklah bersesuaian dengan sifat aset bagi wakaf bagi memelihara modal aset wakaf dan menjamin kemaslahatan benefisiari yakni sekiranya harta merupakan harta alih hendaklah dipastikan pemilikannya tidak hilang dan sekiranya dalam bentuk wang hendaklah dilaburkan menerusi akad-akad seperti mudārabah, mushārakah, istisnā' dan akad-akad yang lain; dan pengurus pelaburan hendaklah bersikap telus dalam pelaburan daripada segi pelaporan operasi, pendapatan dan agihan manfaat wakaf. ${ }^{105}$

Berdasarkan kepada huraian kriteria pelaburan yang telah dibincangkan, pada dasarnya strategi pelaburan harta wakaf secara lestari perlu dilaksanakan secara berhati-hati dan berhemah dengan mengambil kira beberapa faktor penting yang dapat dirumuskan seperti berikut:

1. Memastikan objektif wakaf tercapai selaras dengan niat pewakaf ${ }^{106}$ dan benefisiari mendapat manfaat hasil daripada pembangunan wakaf.

2. Mengekalkan modal wakaf dan pada masa yang sama menjana pendapatan yang lumayan dan konsisten.

3. Memastikan aset wakaf dilaburkan menerusi kaedah dan instrumen yang patuh Syariah.

4. Melindungi status wakaf bagi menjamin pemilikan aset wakaf terus kekal berada di pihak mutawallī (pemegang amanah).

5. Melantik pengurus pelaburan yang cekap dengan kos pengurusan yang minimal bagi meningkatkan pulangan untuk diagihkan kepada benefisiari.

6. Pengurusan risiko yang cekap dengan menekankan aspek jaminan modal bagi menjamin kemapanan dan kekekalan modal wakaf.

7. Melaksanakan kajian yang komprehensif bagi menentukan tahap risiko yang boleh ditanggung berasaskan kepada prinsip "al-ghunmu bi alghurmī"107 iaitu keuntungan adalah melalui penanggungan risiko.

8. Melakukan pempelbagaian (diversification) daripada segi instrumen dan sektor pelaburan bagi menangani risiko dan menjamin pulangan yang stabil.

9. Melaksanakan pempelbagaian berasaskan kepada kedudukan geografi dan

105 Majma Fiqh al-Duwali, 11 Mac 2004, Keputusan No. 140 (6/15), Oman.

106 Zaini Osman, 'Financing Models for Enhancing Waqf Asset in Singapore', (Seminar Waqaf Antarabangsa 2014, Hotel Istana Kuala Lumpur, 8-10 Disember 2014).

107 Al-Nadwi Ahmad. A, al-Qawā id Al-Fiqhiyyah (Syria: Dār al-Qalām, 2000), 411; Artikel 87, Majallah al-Ahkam al-'Adliyyah. 
peka terhadap peraturan berkaitan wakaf dan endowmen di negara-negara luar bagi memelihara kekekalan aset wakaf.

10. Pengurus pelaburan dan mutawallī hendaklah bersikap telus dalam pelaburan daripada segi pelaporan operasi, pendapatan dan agihan manfaat wakaf bagi memberi lebih keyakinan kepada orang awam untuk berwakaf.

Sebagai salah satu pendekatan awal bagi institusi wakaf di Malaysia yang berkemungkinan kurang berpengalaman dalam aspek pengurusan pelaburan, model pelaburan yang dilaksanakan oleh beberapa endowmen terkemuka seperti Yale Endowment dan Harvard Endowment mungkin boleh diaplikasikan terutama sekali daripada segi strategi pengelasan aset (asset allocation) dalam pelaburan misalnya dengan memberi tumpuan terhadap pelaburan dalam ekuiti swasta (private equity). Dalam hal ini, entiti wakaf menerusi kajian yang komprehensif dapat mengenal pasti syarikat-syarikat persendirian di Malaysia yang mempamerkan prestasi yang cemerlang di samping telah terbukti dalam memberi pulangan yang kompetitif dan konsisten kepada para pelabur sebagai antara syarikat-syarikat yang berpotensi untuk membuat pelaburan.

Selain itu, penekanan juga harus diberikan agar pengelasan aset pelaburan harta wakaf dibuat dalam sektor yang patuh Syariah sahaja sebagaimana yang telah ditawarkan dalam sektor pasaran modal Islam di Malaysia. Industri pasaran modal Islam di Malaysia telah diperakui mempunyai landskap kewangan dan perundangan yang komprehensif yang dikawal ketat oleh Majlis Penasihat Suruhanjaya Sekuriti Malaysia menerusi resolusi-resolusi kewangan Islam yang dinamik sejajar dengan keperluan dan tuntunan semasa yang sewajarnya dimanfaatkan oleh semua institusi wakaf di negara ini.

\section{KESIMPULAN}

Aspek pembangunan, pendanaan dan pelaburan adalah tiga faktor utama yang saling berkaitan dalam menentukan hala tuju institusi wakaf di Malaysia. Strategi pelaburan harta wakaf secara mantap yang menggabungkan aspek penghayatan terhadap objektif penubuhan wakaf, pematuhan prinsipprinsip Syariah dalam mekanisme pelaburan, strategi peruntukan aset (aset allocation), pempelbagaian pilihan pelaburan, serta pengurusan risiko yang cekap menerusi jaminan pengekalan modal aset wakaf merupakan antara faktor yang penting bagi memaksimumkan pulangan pelaburan wakaf. Di samping itu, pengurusan agihan manfaat wakaf secara telus, berintegriti dan penuh akauntabiliti oleh semua pentadbir wakaf di Malaysia juga amat signifikan ke arah meningkatkan keyakinan dan kepercayaan rakyat Malaysia untuk membudayakan amalan berwakaf. Wakaf merupakan suatu cabang 
dalam bidang muamalat yang terbuka luas padanya pintu ijtihad selaras dengan ciri-ciri murūnah (fleksibiliti) dalam perundangan Islam lebih-lebih lagi dalam aspek yang melibatkan kemaslahatan ummah. Anjakan paradigma perlu direalisasikan oleh semua pentadbir dan pengurus wakaf di Malaysia ke arah mentransformasikan institusi wakaf sebagai agen yang mempromosikan pertumbuhan dan kemajuan sosio ekonomi ummah bagi mengatasi insiden kemiskinan dan kemunduran yang mencengkam sebahagian besar umat Islam di seluruh dunia. Secara tuntasnya, konsep pembangunan dan pelaburan harta wakaf secara lestari menurut perspektif Islam merangkumi dimensi yang begitu syumul lantaran berpaksikan nilai-nilai spiritual (ketauhidan kepada Allah) dan material bagi mencapai matlamat al-falāh yakni kecemerlangan ummah secara mampan di dunia dan akhirat.

\section{RUJUKAN}

Ali, Ashfaque, 'Socio-economic Role of Awqaf in the Advancement of Muslims,' Awqaf, 3 (2002): 21-30.

Abbas, Abdelraman B.M., 'The Economics of Benevolence: An Islamic Paradigm,' (Tesis Ijazah Doktor Falsafah, University of Wales, 1990).

Ab̄̄ Muḥammad 'Abd Allāh bin Aḥmad bin Muḥammad bin Qudāmah, alMughnī, vol. 8 (Arab Saudi: Dār 'Alam al-Kutub, 1997).

Al-Abiy al-Alzariy, Șālih 'Abd al-Sāmi', Jawahir al-Iklil fì Madhhab al-Imām Mālik, vol. 2 (Qāhirah: 'Isa al-Bābī al-Halābī, 1970).

Abu Bakar Yang, 'Pembangunan Wakaf(Perbadanan Wakaf Negeri Selangor),' (Kertas kerja yang dibentangkan dalam Seminar Waqaf Antarabangsa 2014, Hotel Istana Kuala Lumpur, 8-10 Disember 2014).

Ahmad, Kurshid, 'Economic Development in An Islamic Framework,' in Studies in Islamic Economics, ed. Ahmad, Kurshid (Leicester: Islamic Foundation, 1980).

Ainul Jaria Maidin \& Omar Oseni, 'Islamic Principles on Sustainable Land Use Planning and Development,' Journal of Islamic Law Review, 7/1 (Jun 2011): 57-89.

Md. Akhir Haji Yaacob (terj.), al-Ahkam al- 'Adliyyah: Undang-Undang Sivil Islam, ed. ke-3 (Kuala Lumpur: Dewan Bahasa dan Pustaka, 1994).

Anan C. Mohd, 'Pembangunan Wakaf-Pengalaman Malaysia,' (Kertas kerja yang dibentangkan dalam Seminar Wakaf Serantau di Hotel Sunway Putra, Kuala Lumpur, 4-5 September 2012).

Anan C. Mohd, 'Senario Pembangunan Waqf di Malaysia: Waqaf Melestarikan Pembangunan Ummah,' (Kertas kerja Seminar Antarabangsa 2014, 710 Disember 2014). 
Ansari, Abdul Haseeb, Jamal, Parveen \& Oseni, Umar A., 'Sustainable Development: Islamic Dimension with Special Reference to Conservation of the Environment,'Advances in Natural and Applied Sciences, 6/5 (2012): 60.

Asyraf Wajdi Dusuki (eds.), Islamic Financial System: Principles and Operations (Kuala Lumpur: International Sharia'h Research Academy for Islamic Finance, 2011).

Baskan, Birol, 'Waqaf System As A Redistribution Mechanism In Ottoman Empire,' (Kertas kerja yang dibentangkan dalam seminar 17th Middle East History and Theory Conference, Center for Middle Eastern Studies, University of Chicago, 10-11 Mei 2002).

Brown L. D., \& Mark H. M., Accountability, Strategy and International Non-Governmental Organizations. The Hauser Center for Nonprofit Organizations (Harvard: The Kennedy School, Harvard University, 2001).

Bryce, Herrington J., Financial \& Strategic Management for Nonprofit Organizations, A Comprehensive Reference to Legal, Financial, Management and Operations Rules and Guidelines for Nonprofits, $3^{\text {rd }}$ ed. (San Francisco: Jossey-Bass, 2000).

Al-Busharah, Khaled M., 'Kuwait Awqaf Public Foundation, (KAPF), Developmental Social Experience and Prospects,' (Kertas kerja yang dibentangkan dalam The Arab Forum Towards A New Welfare Mix: Rethinking the Role of the State, Market and Civil Society in the Provision of Basic Social Services, Beirut, 19-20 Disember 2012).

Cizacka, Murat, 'The Waqf, Its Contribution and Basıc Operational Structure,' (Kertas seminar Waqf Redefining Prosperity and Growth, International Centre for Education in Islamic Finance (INCEIF), Kuala Lumpur, 15 Disember 2011).

Cizakca, Murat, A History of Philanthropic Foundations, The Islamic World From the Seventh Century to the Present (Istanbul: Bogazici University Press, 2000).

Harvard Management Company Endowment Report 2013.

Harvard Management Company, 'Message from CEO', Annual Endowment Report (September 2014).

Hidayatul Ihsan \& Shahul Hameed Hj. Mohamed Ibrahim, 'Waqf Accounting and Possible Use of SORP 2005 to Develop Waqf Accounting Standards,' dalam Essential Readings in Contemporary Waqf Issues, ed. Kahf, Monzer \& Siti Mashitoh Mahamood (Kuala Lumpur: CERT Publication, 2011), 353-385. 
Ibn 'Abidin, Muhammad Amin, Radd al-Mukhtar 'ala Dur al-Mukhtar Sharh Tanwir al-Abṣār, vol. 6 (Riyāḍ: Dār al-'Alim al-Kutub, 2003).

Ibn al-Humam, Sharh Fath al-Qadir, vol. 6 (Beirūt: Dār al-Kutub al-'Ilmiyyah Al-Imām Malik bin Anas, al-Mudawwanah al-Kubra, vol. 4 (Beirūt: Dār alKutub al-'Ilmiyyah, t.t.).

International Shariah Research Academy for Islamic Finance (ISRA). ISRA Compendium for Islamic Financial Terms: Arabic-English (Kuala Lumpur: International Shariah Research Academy for Islamic Finance (ISRA), 2010).

Investopedia, http://www.investopedia.com/terms/e/endowment.asp, 6 September 2014.

Jabatan Kemajuan Islam Malaysia, Tafsir Pimpinan al-Rahman, terj. Sheikh Abdullah Basmeih (Kuala Lumpur: JAKIM, 2011).

Jabatan Wakaf Zakat dan Haji, 'Rumusan dan Resolusi,' (Seminar Waqaf Antarabangsa 2014, Hotel Istana Kuala Lumpur, 8-10 Disember 2014).

Kahf, Monzer, Asasiyyat al-Tamwil al-Islami (Kuala Lumpur: ISRA, 2011).

Kahf, Monzer, 'Towards the Revival of Awqaf: A New Fiqhi Issues to Reconsider,' (Kertas kerja yang dibentangkan dalam seminar Harvard Forum on Islamic Finance and Economics, Harvard University, U.S.A, 1 Oktober 1999).

Khan, Muhammad Akram, 'The Future of Islamic Economics,' Futures, 23/3 (1991): 248-261.

Al-Khin, Mustafa dan al-Syarbaji, 'Ali, al-Fiqh al-Manhaji 'ala Mazhabi alImam al-Syafi i, Kitab Wakaf, Wasiat dan Faraid, terj. Jilid ke-5. (Kuala Lumpur: Pustaka Salam Sdn Bhd.).

Kuran, Timur, 'The Provision of Public Goods under Islamic Law: Origins, Impact, and Limitations of the Waqf System,' Law and Society Review, 35/4 (2001): 841-898.

Kuran, Timur, 'The Economic Roots of Political Underdevelopment in the Middle East: A Historical Perspective,' Southern Economic Journal, 78/4 (2012): 1086-1095.

Kuran, Timur, 'Why the Middle East is Economically Underdeveloped: Historical Mechanisms of Institutional Stagnation,' The Journal of Islamic Economic Perspectives, 18/3 (2012): 71-90.

Kuran, Timur, 'The Absence of the Corporation in Islamic Law: Origins and Persistence,' American Journal of Comparative Law, 53/4 (2005): 785834. 
Lane, Jan-Erik, Redissi, Hamadi dan Șaydawi, Riyaḍ, Religion and Politics: Islam and Muslim Civilization (England: Ashgate Publishing Limited, 2009).

Magda Ismail Abdel Mohsin, 'Revitalization of Waqf Administration and Family Waqf Law,' China Law Review, 7/6 (June 2010): 1-8.

Magda Ismail, 'What We Can Do With Waqf Properties,' (Kertas kerja yang dibentangkan dalam Roundtable Discusssion on Development Waqf Properties in Malaysia, Sasana Kijang, Bank Negara Malaysia, Kuala Lumpur, 21 Januari 2014).

Majma Fiqh al-Islami al-Duwali, http://www.fiqhacademy.org.sa/, 11 Mac 2014.

Mansur bin Yusuf al-Buhuti, Kasshaf al-Qina' 'an al-Iqna', vol. 10 (Arab Saudi:Wizarah al-'Adl).

Mawsu 'at al-Hadith al-Sharif : al-Kutub al-Sittah, ed. Șālih Ibn 'Abd al-'Azīz Ibn Muḥammad Ibn Ibrāhim al-Shaykh (Dār al-Salām, 2008).

Maya, Shatzmiller, 'Islamic Institutions and Property Rights: The Case of the 'Public Good' Waqf,' Journal of Economic and Social History of the Orient, 44/1 (2001): 44-74.

Maya, Shatzmiller, 'Economic Performance and Economic Growth in the Early Islamic World,' Journal of the Economic and Social History of the Orient, 54/2 (2011): 132-184.

Miswan@Abdul Hakim et al., 'Pembangunan Harta Tanah dan Pelestarian Alam,' (Kertas kerja yang dibentangkan dalam Seminar Pembangunan Harta Tanah Kebangsaan Menurut Perspektif Islam, Institut Kefahaman Islam Malaysia, Kuala Lumpur, 11-12 Ogos 2009).

Mohammad Obaidullah, 'Waqf Development: Islamic Development Bank Experience,' (Kertas kerja yang dibentangkan dalam Seminar Wakaf Kebangsaan 2014, Hotel Istana Kuala Lumpur, 7-8 Disember 2014).

Mohammad Tahir Sabit Mohammad, 'Sustaining the Means of Sustainability: The Need for Accepting Wakaf (Wakaf) Assets in Malaysian Property Market,' (Kertas kerja yang dibentangkan dalam Seminar the 14th Annual Conference of the Pacific Rim Real Estate Society, Kuala Lumpur, 20-23 Januari 2008).

Mohd Afandi Mat Rani et al., Transformasi Wakaf di Malaysia: Isu dan Cabaran (Shah Alam: Institut Kajian Zakat Malaysia, Universiti Teknologi Mara, t.t.). 
Mohd Daud Bakar, 'Konsep dan Matlamat Harta dalam Pembangunan Ummah,' dalam Pentdbiran Harta Menurut Islam, ed. Abdul Monir Yaacob dan Mohd. Fauzi Mustaffa (Kuala Lumpur: IKIM, 1999).

Mohd Zain Haji Othman, Islamic Law with Special Reference to the Institution of Waqf (Kuala Lumpur: Jabatan Perdana Menteri, 1982).

Mohd. Daud Bakar, 'Amalan Institusi Wakaf di Beberapa Negara Islam,' dalam Konsep dan Pelaksanaan Wakaf di Malaysia, ed. Nik Mustapha Nik Hassan (Kuala Lumpur: Institut Kefahaman Islam Malaysia (IKIM), 1999).

Monzer Kahf, 'Financing the Development of Awqaf Property,' (Kertas kerja yang dibentangkan dalam Seminar on Development of Awqaf, Kuala Lumpur, 2-4 Mac 1998).

Muhammad M. al-Arnawut, Dawr al-Waqfi al-Mujtami'at al-Islamī(Lubnan: Dar al-Fikr al-Mu'asir, 2000).

Al-Nadwī Aḥmad. A., al-Qawā 'id al-Fiqhiyyah (Syria: Dār al-Qalam, 2000).

al-Nawawī, Muḥy al-Dīn, al-Majmū' Sharh al-Muhaddhab li al-Shirazi, vol. 16 (Jeddah: Maktabah al-Irsyad, t.t.).

Ni'mat 'Abd al-Latif Masyhur, Athar al-Waqf fi Tanmiyyah al-Mujtama'. (Qāhirah: Markaz Șāliḥ ‘Abd Allāh Kāmil li al-Iqtiṣād al-Islāmī, Jāmi'ah al-Azhar, 1997).

Nik Mohd Zain Haji Yusof dan Azimuddin Bahari, 'Kedudukan dan Potensi Pembangunan Hartanah Wakaf di Malaysia: Satu Penilaian,' dalam Konsep dan Pelaksanaan Wakaf di Malaysia, ed. Nik Mustapha Nik Hassan (Kuala Lumpur: Institut Kefahaman Islam Malaysia (IKIM), 1999).

Nor Sharina Mohd Rafien et al., 'Not-For-Profit Religious Organization in Malaysia: A Case on Zakat Institution,' dalam Islamic Philanthropy for Ummah Excellence, ed. Noraini Mohamad et al. (Kuala Lumpur: Institute Kajian Zakat Malaysia, Universiti Teknologi MARA.

Noraini Md Top, 'Mobilisation of Waqf Resources in Malayisa: Problems and Prospects,' (Disertasi Sarjana, Universiti Islam Antarabangsa Malaysia, 1991).

Nuffield F.I.S, 'Endowments, Volatility and Time,' (Kertas kerja yang dibentangkan dalam Nuffield Foundation Investment Seminar, 5 Mac 2007).

Sait, Siraj dan Lim, Hilary, Land Law and Islam: Property Human Rights in the Muslim World (London: Zed Books Ltd., 2006). 
Securities Industry Development Corporation (SIDC), Soal Jawab Pelabur, Langkah Permulaan Pelaburan (Kuala Lumpur: SIDC, 2009).

Shams al-Dīn al-Sarakhsī, al-Mabșūt, vol. 12 (Beirut: Dar al-Ma'rifah, t.t.).

Shams al-Din Muhammad bin al-Khatib al-Sharbini, Mughni al-Muhtaj ila Ma'rifati Alfaz al-Minhaj, vol. 8 (Beirut: Dar al-Ma'rifah, 1997).

Shamsiah Abdul Karim, 'Contemporary Shari'a Compliance Structuring for the Development and Management of Waqf Assets in Singapore', Kyoto Bulletin of Islamic Area Studies, 3/2 (2010): 143-164.

Shamsiah Abdul Karim, 'Contemporary Investment and Development of Waqf Assets in Singapore,' (Kertas kerja yang dibentangkan dalam International Islamic Capital Market Forum, Sasana Kijang, Kuala Lumpur, 20 September 2012).

Shamsiah Abdul Karim, 'Contemporary Shari'ah Structuring for the Development and Management of Waqf Assets in Singapore,' (Tesis Ph.D, Durham University, 2010).

Shukti Adam dan Ahcene Lahsana, 'Cash Endowment As Source of Fund in Islamic Micro-Financing,' (Kertas kerja yang dibentangkan dalam 4th International Conference on Business and Economic Research (4th ICBER 2013), Bandung Indonesia, 4 Mac 2013).

Slim, Hugo, 'What is Development,' Development in Practice, 5/2 (May, 1995).

al-Tarabulsi, Burhān al-Dīn Ibrāhim bin Mūṣā bin Ab̄̄ Bakr ibn al-Shaykh 'Alī, al-Is 'af fì al-Aḥām al-Awqāf (Mesir: Matba'ah Hindiyyah, 1902).

Timur Kuran, Islam and Mammon: The Economic Predicaments of Islamism (Princeton University Press, Princeton and Oxford, 2004).

Tunku Alina Raja Muda Alias, 'Unleashing the Potential of the Waqf As an Economic Institution in Malaysia: Policy, Legal and Economic Reforms,' (Tesis Ph.D, International Centre for Education in Islamic Finance).

Wildermuth, Daniel, How the Smart Money Invests. Wise Money. Using Endowment Investment Approcah to Minimize Volatility and Increase Output (New York: Mc Graw Hill, 2012).

Yale Endowment 2013.

Yale University Investment Office, http://investments.yale.edu/, 11 Disember 2014.

Yediyyildiz, B., 'Place of the Waqf in Turkish Cultural System,' (Kertas kerja yang dibentangkan dalam Seminar Habitat II, Istanbul, 12 April 1996). 
Zaini Osman, 'Financing Models for Enhancing Waqf Asset in Singapore,' (Seminar Waqaf Antarabangsa 2014, Hotel Istana Kuala Lumpur, 8-10 Disember 2014).

Al-Zarqa, Muștafāa Aḥmad, al-Aḥkām al-Awqā̃f ('Amman: Dār 'Ammar, 1998). Ziauddin Sardar, 'Beyond Development: An Islamic Perspective,' The European Journal of Development Research, 8/2 (Special Issue: Cultural Perspectives on Development, 1996), 47.

\section{Temu bual}

Abdul Wahab Othman (Penolong Pengurus Hartanah, Bahagian Pembangunan dan Pelaburan Majlis Agama Islam Wilayah Persekutuan Kuala Lumpur), dalam temu bual beliau dengan penulis, pada 5 September 2014.

Fakhruddin Abd Rahman (Ketua Bahagian Wakaf, Majlis Agama Islam Pulau Pinang), dalam temu bual beliau dengan penulis, pada 17 Julai 2014.

Hamizah Jais (Penolong Eksekutif Kewangan, Perbadanan Wakaf Selangor), dalam temu bual beliau dengan penulis, pada 16 Oktober 2014.

Mustapa Hayuddin Abdul Halim (Penolong Pengarah Wakaf, Pejabat Wakaf, MAIN Agama Islam Johor), dalam temu bual beliau dengan penulis, pada 26 September 2013.

Shamsiah Abdul Karim (Penolong Pengarah, Bahagian Wakaf, Majlis Agama Islam Singapura), dalam temu bual beliau dengan penulis, pada 30 April 2012. 